\title{
A descriptive analysis of Regal Fritillary (Speyeria idalia) habitat utilizing biological monitoring data along the big bend of the Platte River, NE
}

\author{
Andrew J. Caven ${ }^{1} \oplus$ - Kelsey C. King ${ }^{1} \cdot J^{\prime}$ oshua D. Wiese ${ }^{1} \cdot$ Emma M. Brinley Buckley $^{2}$
}

Received: 20 May 2016 / Accepted: 14 March 2017 / Published online: 29 March 2017

(C) The Author(s) 2017. This article is an open access publication

\begin{abstract}
Speyeria idalia populations have declined as much as 95 percent over the last three decades. Here we critically evaluate prairie habitat components along the Platte River in central Nebraska that $S$. idalia populations require in an effort to better inform conservation efforts. We utilized S. idalia count data from biological monitoring transects where vegetation, soils, land management, and flooding frequency data were also collected to describe the habitat constituents associated with $S$. idalia presence. We utilize comparative statistics, Pearson's correlation analysis, and random forest analysis to model $S$. idalia habitat on land owned and managed by a small conservation NGO. Our findings suggest that $S$. idalia occupies specific habitat niches with a preference for well-drained soils (Inavale series) dominated by facultative upland plants, most prominently Andropogon gerardii. S. idalia is positively associated with large connected tracts of relict prairie containing
\end{abstract}

Electronic supplementary material The online version of this article (doi:10.1007/s10841-017-9968-0) contains supplementary material, which is available to authorized users.

Andrew J. Caven

acaven@cranetrust.org

Kelsey C. King

kking@cranetrust.org

Joshua D. Wiese

wiesejd@lopers.unk.edu

Emma M. Brinley Buckley

emma.brinley.buckley@huskers.unl.edu

1 Platte River Whooping Crane Maintenance Trust, $6611 \mathrm{~W}$ Whooping Crane Drive, Wood River, NE 68883, USA

2 Nebraska Cooperative Fish and Wildlife Research Unit, University of Nebraska-Lincoln, Lincoln, NE 68583-0984, USA
Viola sororia and very moderate management regimes that remove shrubby cover (negatively associated) and promote forb cover (positively associated), while providing ample recovery time on burned and grazed patches for litter development (positively associated). Random forest analysis describes the presence of $V$. sororia, percent forb cover, and habitat isolation as the top three habitat variables of importance in predicting the presence/absence of $S$. idalia. Our finding that habitat isolation is a major predictor of $S$. idalia absence suggests many populations may be both spatially and genetically isolated. S. idalia's future demands the preservation of tallgrass prairie fragments under management regimes that promote healthy populations and habitat connectivity.

Keywords Butterfly $\cdot$ Habitat - Conservation · Management $\cdot$ Tallgrass prairie $\cdot$ Regal fritillary

\section{Introduction}

Relict tallgrass prairie has become a priceless resource throughout the central United States. It is estimated that over $97 \%$ of the tallgrass prairie in Nebraska has been lost (Noss et al. 1995). The once vast tallgrass prairies of eastern Nebraska are the most endangered ecosystem in the state with an estimated $99 \%$ of that system now eliminated (Ratcliffe and Hammond 2002). The isolated areas of tallgrass prairie further west in the state remain relatively more intact. Their fertile soils are ideal for agriculture and the depletion of contiguous habitat is attributed to the expansion of corn and soybean monocultures. As more virgin land was converted to cropland, populations of tallgrassendemic species have sharply declined. An especially drastic example is the Regal Fritillary (Speyeria idalia 
Drury) where one survey program has the national population decreasing by $75-95 \%$ since 1990 (Swengel 2015). Whether this recent decline is a part of continuing habitat loss, or has some other etiology, it is certainly part of a global decline of Lepidoptera (Dover et al. 2011). Consequently, for the past two decades $S$. idalia has been listed in many states as a species of conservation concern and is currently a candidate for the federal endangered species list (Selby 2007). Investigations into both the characteristics of prairies where Regal Fritillaries make their homes and population trends in these areas are needed if we hope to aid this species to a stable (non-declining) state. Throughout their range these butterflies are found in isolated pockets (Swengel 2015; Selby 2007). In the western extent of their range, these pockets generally become more isolated as patches of appropriate tallgrass prairie habitat become smaller and tied to comparatively mesic lowlands that accumulate just enough moisture to maintain a tallgrass community. The Platte River of Nebraska is a unique system that naturally extends the range of the tallgrass prairie westward into the predominantly mixed grass prairie system typical of the rain and snowfall regimes in central Nebraska (Kaul and Rolfsmeier 1993). Tallgrass prairies of this region persist in a mosaic along with subirrigated wet meadows and cottonwood woodlands (Currier 1982). The Platte River system exists in the western range of the Regal Fritillary and its habitat requirements have not been intensively investigated in this context. Helzer and Jasnowski (2011) conducted an investigation into prairie management techniques and their differential impacts on S. idalia along the Big Bend of the Platte River in central Nebraska; however, there has yet to be an exhaustive study of the habitats $S$. idalia utilizes in this area. Here we examine and distinguish the unique traits of the lowland tallgrass prairie where $S$. idalia resides and contrast that with habitats they do not utilize in the central Platte River Valley, NE. We examine soil, vegetation, and land use history data overlaid with Regal Fritillary survey count data from biological monitoring efforts to better describe the habitat associations of S. idalia along the Big Bend of the Platte River in central Nebraska.

The Regal Fritillary (henceforth described as "Regals" or "Regal") is a univoltine butterfly (reproducing once per year with eggs that overwinter) that feeds on violet species (Viola spp.) as larvae and does not lay eggs directly on a host plant, but rather indiscriminately within its prairie home (Wagner et al. 1997). However, Kopper et al. (2000) demonstrates that egg placement is not random in nature but variously distributed in shady microsites with extensive live plant and litter cover. This cover probably protects larvae from extreme weather conditions (Kopper et al. 2000). Regals have a strong preference against dispersal; for example, one study found no evidence of migration across only $4 \mathrm{~km}$ of a disturbed field (Ferster and Vulinec 2010). The combination of these two behavioral traits has contributed to their fragmented distribution bolstering current concerns regarding Regal population declines. Regals are almost always found in areas of relict prairie (Powell et al. 2007; Shepherd and Debinski 2005a; Kelly and Debinski 1998). The Regal is a part of the 'prairie butterfly paradox', wherein a disturbance sensitive species is dependent on a disturbance reliant system (tallgrass prairie) making it prone to extirpation, and, eventually, extinction (Moranz et al. 2014). An extreme preference for a certain habitat is clear; however, it is not clear exactly what drives Regals to cling to the few remnant patches of prairie they still inhabit. It may be that tallgrass prairie restoration efforts commonly lack crucial components (e.g. seed mixes excluding Viola spp.) or that the behavioral resistance to dispersion is so strong that natural colonization of restored prairie is improbable. Efficient monitoring of Regal populations across distinctive habitats is necessary to better elucidate the character and ecological complexity of those sites where remnant populations persist throughout their range, to evaluate the sustainability of this susceptible species, and ensure a future for them where possible.

Not all relict prairies support Regals (Kelly and Debinski 1998; Ries and Debinski 2001). In addition to other natural pressures (predation, flooding, disease etc.), spring and fall fires used for managing prairies will result in larval death (Wagner et al. 1997; Swengel and Swengel 2007; Shepherd and Debinski 2005b; Selby 2007; Swengel et al. 2011; Moranz et al. 2014), attesting to the ability of land management practices to vastly influence localized populations of Regals. High frequency fires (annual, biennial) are problematic for Regal populations, especially when combined with intensive grazing across entire prairies or pastures (Moranz et al. 2014; Huebschman and Bragg 2000; Swengel et al. 2011). However, burning and/or grazing at limited spatial and temporal scales may not be detrimental (i.e. patch burn-grazing; Helzer 2012; Moranz et al. 2014). Swengel and Swengel (2009) documented a higher average number of Regals in pastures managed with rotational burning and grazing as opposed to simply rotational burning, grazing, or no management; Regal abundance was highest 1 year following a burn, declined in year 2, and rebounded in years 3 and 4. By contrast, Swengel et al. (2011) found that prairie specialist butterflies, including Regals, had non-random declining trends on large high quality fire-managed preserves, suggesting that prairie specialist butterflies may not be well adapted to current applications of fire. We accept the view of Collins (1990) that fires are natural disturbances in tallgrass prairie systems and have historically structured them. However, the historical frequency and timing of fires, and how those variables relate to native grazers is not fully understood (Anderson 
1990). Controlled burning is utilized to mimic the effects of natural wildfires and is effective in setting back woody plant encroachment for species such as Eastern Red Cedar (Juniperus virginiana) in tallgrass prairie systems (Bragg and Hulbert 1976; Gibson and Hulbert 1987; Briggs et al. 2002a; Twidwell et al. 2013). Interestingly, grazing can often reduce the effectiveness of fire in controlling shrub encroachment by reducing the amount of fine fuels (Briggs et al. 2002a). In some cases, grazing in combination with fire, or fire alone, will actually promote the propagation of certain woody species (Briggs et al. 2002b; Abrams and Hulbert 1987). However, controlled burning generally prevents highly invasive woody species from maturing, becoming dominant, and altering the structure and composition of tallgrass prairie ecosystems (Bragg and Hulbert 1976; Gibson and Hulbert 1987; Briggs et al. 2002a; Twidwell et al. 2013; Abrams and Hulbert 1987). This is true of the Platte River Valley, which is a system that has been historically very dependent on a variety of disturbance regimes (flooding, fire, and grazing) to maintain the mosaic of wet meadows, riverine wetlands, and tracts of lowland tallgrass prairie (Currier 1982; Helzer 2009). Gibson and Hulbert (1987) note that species diversity peaks 6-7 years after a fire in a tallgrass prairie system before beginning to decline, whereas shrub encroachment increases at a linear rate following a controlled burn. The use of fire as a vegetation management practice has been shown to negatively impact Regal populations, inhibiting post-fire population growth for up to 7 years or more (Swengel and Swengel 2007; Swengel et al. 2011; Vogel et al. 2007, 2010; Helzer 2012). Conversely, because fire has been demonstrated to have a stimulating effect on forb abundance and diversity, recovery times of Regals may be exaggerated in some systems (Henderson 1990; Helzer 2012; Moranz et al. 2014; Farhat et al. 2014; Davis et al. 2007; Vogel et al. 2010; Gibson and Hulbert 1987). We investigate the land use history of our study area for insights into the impacts of fire, grazing, and other management practices on Regal populations; we expect that areas of frequent intensive disturbance (grazing, fire, and haying) or advanced woody encroachment will not have active Regal populations.

Alongside land management, prairie-specific traits such as spatial scale must be also considered. Regal populations typically remain stable in prairies of 70 ha (170 acres) or more (depending on region; Shepherd and Debinski 2005b; Kelly and Debinski 1998; Mason 2001). It is probable that only these large intact prairies provide enough habitat and connectivity to maintain this dispersal-averse species (Auckland et al. 2004). The importance of management and prairie size is widely agreed upon, though prairie size varies depending on the productivity of the region, as is the importance of violet species (Viola spp.), which are the obligate food source for larvae survival (Kelly and Debinski
1998). Regals are also associated with areas of high native floral diversity and abundance (Davis et al. 2007; Farhat et al. 2014). Other characteristics of Regal habitat still lack investigation. Research indicates that Regals seem to prefer areas with thatch and little bare ground, but few have quantified this balance (Davis et al. 2007; Helzer 2012; Vogel et al. 2007). Some research indicates that warm season grasses such as Big Bluestem (Andropogon gerardii) and a specific soil moisture constitute preferred Regal habitat (Mason 2001; Swengel 1997). Intensive plant and soil based habitat evaluations are lacking for most sites with Regals, creating the need for an in-depth investigation (Ferster and Vulinec 2010; Mason 2001). We investigate a unique tallgrass prairie ecosystem along the Platte River in Nebraska where a metapopulation of Regals resides. We incorporate soil profiles, vegetation communities, hydric regimes, land management histories, and Regal count data collected at biological monitoring plots into a comparative analysis to investigate the variation between plots with and without Regals. We then utilize linear and machine learning analyses to examine the importance of particular variables in predicting Regal presence at monitoring plots and propose a path model for determining adequate Regal habitat. Finally, we make recommendations for future research regarding habitat management for Regals based on our findings and the existing literature.

\section{Methods}

\section{Sampling methods}

In the spring of 2015 we implemented a long-term, landscape-level biological monitoring plan across 1942 ha (4800 acres) of prairie, wet meadows, and woodland habitat at the Crane Trust, a small non-profit conservation organization along the Big Bend of the Platte River near Wood River, Nebraska, USA. The terrestrial portion of the monitoring plan included vegetation monitoring plots spatially overlaid with wildlife monitoring transects including butterfly species of concern surveys. Transect bearings and starting points were randomly placed within polygons, which delineated differing ecotopes (soil and plant communities) within management units (pastures with a shared management history). Polygons were created by overlaying soil maps, land use history maps, and aerial imagery considering the vegetative community, topography, and flooding frequency (Herrick et al. 2009). In creating this stratified random sampling approach we utilized 20 years of Google Earth (2015) aerial imagery from 1993 to 2013, the Web Soil Survey's (USDA-NRCS 2015) soil map data, historic aerial imagery from 1938 (US Bureau of Reclamation 1938), and internal Crane Trust documents describing 
the land use and management histories of all management units. Special consideration was given to capturing the various vegetative communities present in the landscape when designing the monitoring plot layout (Currier 1982). In total this process yielded 56 permanent monitoring transects throughout the Crane Trust's property, where comprehensive growing season vegetation, avian, small mammal, and butterfly species of concern surveys have been and will continue to be conducted. This compiled data will help describe components of each ecotope, which will be used to compare and contrast variability between plots with and without Regals and describe the habitat related variables associated with Regal presence (For "ecotype" see Naveh 1994).

Our study area regarding this research is centered on Shoemaker Island; a tract of land bordered on both the north and south sides by the Platte River. We sampled all pastures and monitoring plots within a $2000 \mathrm{~m}$ circular buffer of the historically known Regal population. This distance was chosen considering what is known and hypothesized regarding the dispersal potential of Regals and comparable butterfly species (Auckland et al. 2004; Ries and Debinski 2001; Ferster and Vulinec 2010). Our sampling area included nine management units (pastures) and 17 biological monitoring plots (estimated 503 ha (1244 acres) of pasture; Fig. 1). Larger and more structurally diverse pastures in terms of vegetation, soils, and management history included more monitoring plots (Table 1).

We summarized the land management history of all pastures in the study area over the last 10 years (2006-2015) utilizing internal Crane Trust documentation (Table 1). Land management records over the last 10 years were not detailed enough to summarize land management data at the monitoring plot-level. We developed indices based on management intensity, scale, and frequency to organize and summarize pasture-level land management data. A 6-point scale was utilized to assess annual grazing with " 0 " indicating "no grazing" and a " 5 " indicating "heavy grazing" on each pasture (Bruhjell and Moore 2003; Kothmann and Hinnant 1993). For each pasture we averaged yearly grazing levels across 10 years and lumped data into one of three categories, "light", "moderate", or "heavy" grazing.

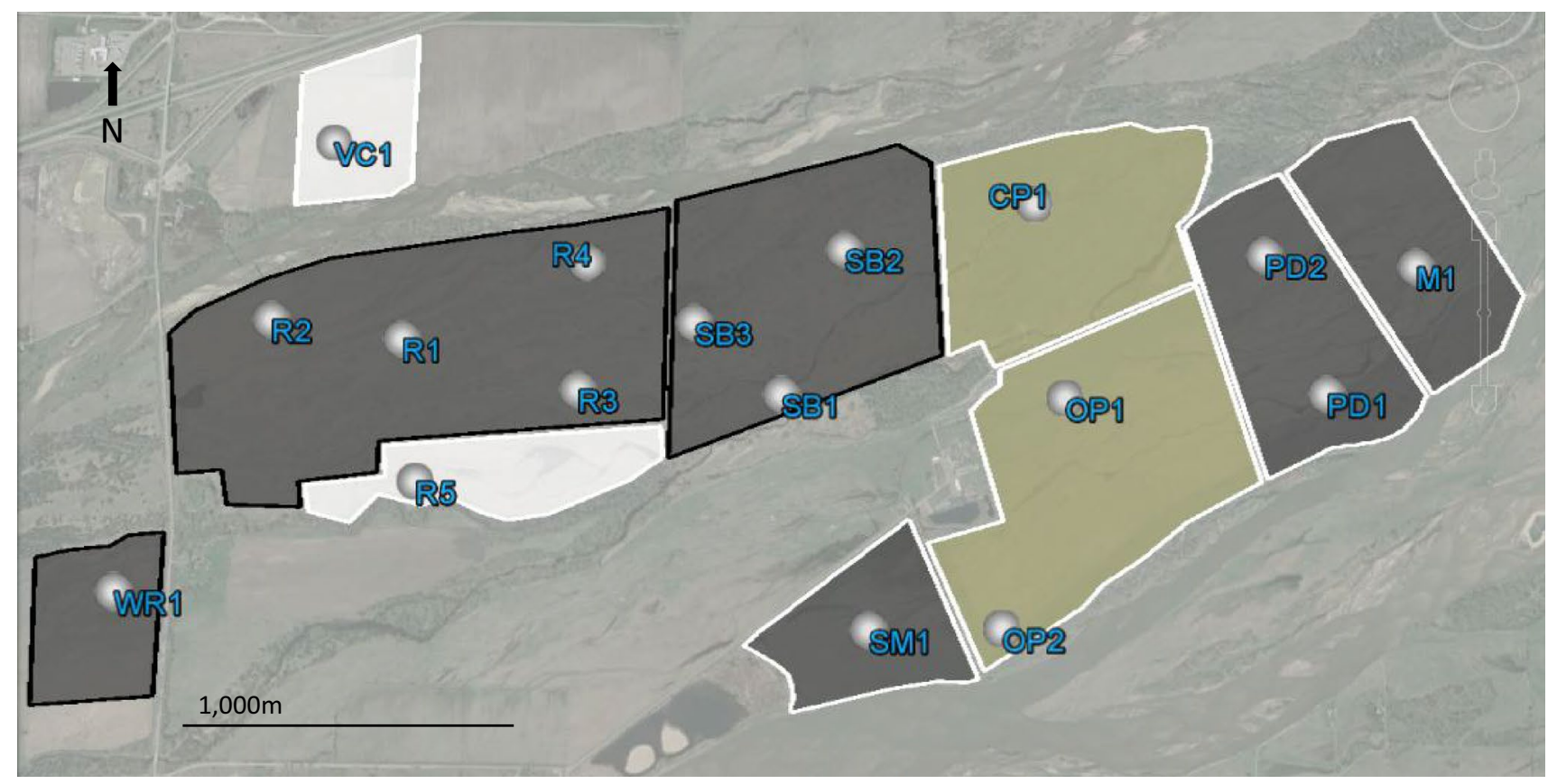

\footnotetext{
- Monitoring plot name- "R1", "R2", etc.

Relict - never tilled, never seeded with exotics, community intact

Restored - never tilled, seeded with exotics historically, community not fully intact

Reconstructed - tilled as agriculture, prairie reconstructed (soil work, seeding)

Management unit contains no regal fritillaries

Management unit contains regal fritillaries
}

Fig. 1 Regal study area: management units, land use histories, and habitat monitoring plots 
Table 1 Summary of previous 10 years of pasture-level land management data in Regal study area

\begin{tabular}{|c|c|c|c|c|c|c|c|c|c|}
\hline $\begin{array}{l}\text { Pasture } \\
\text { (abbreviation) }\end{array}$ & ha (size) & \# Mon. plots & Historic use & $\begin{array}{l}\text { Rested (in } \\
10 \text { years) }\end{array}$ & $\begin{array}{l}\text { Grazing PY } \\
\text { (last YA) }\end{array}$ & $\begin{array}{l}\text { Burning PY } \\
\text { (last YA) }\end{array}$ & $\begin{array}{l}\text { Haying PY } \\
\text { (last YA) }\end{array}$ & $\begin{array}{l}\text { Management } \\
\text { (in } 10 \text { years) }\end{array}$ & $\begin{array}{l}\text { Regals } \\
\text { detected }\end{array}$ \\
\hline Ruge (R) & 115 & 5 & Mostly relict & 2 & Mod. (3) & Infrequent (9) & Light $(9)^{\mathrm{a}}$ & Light-Mod. & Yes \\
\hline $\begin{array}{l}\text { South brown } \\
\text { (SB) }\end{array}$ & 57 & 3 & Relict & 2 & Mod. (1) & None (NR) & None (NR) & Light & Yes \\
\hline $\begin{array}{l}\text { Calving pas- } \\
\text { ture (CP) }\end{array}$ & 45 & 1 & Restored & 0 & Heavy (1) & Infrequent (2) & Light $(0)^{\mathrm{a}}$ & Heavy & No \\
\hline $\begin{array}{l}\text { West Ruge } \\
\text { (WR) }\end{array}$ & 22 & 1 & Partially relict & 1 & Mod. (4) & $\begin{array}{l}\text { Infrequent } \\
(1)^{\mathrm{a}}\end{array}$ & Mod. $(2)^{\mathrm{a}}$ & Mod. & Yes \\
\hline $\begin{array}{l}\text { Office pasture } \\
\text { (OP) }\end{array}$ & 58 & 2 & Restored & 3 & Mod. (3) & Infrequent (6) & None (NR) & Light & No \\
\hline $\begin{array}{l}\text { Prairie dog } \\
\text { (PD) }\end{array}$ & 38 & 2 & Relict & 3 & Mod. (0) & Frequent (1) & None (NR) & Mod.-Heavy & No \\
\hline $\begin{array}{l}\text { Middle pas- } \\
\text { ture (MP) }\end{array}$ & 33 & 1 & Relict & 3 & Mod. (0) & $\begin{array}{l}\text { Mod. frequent } \\
\text { (5) }\end{array}$ & None (NR) & Light-Mod. & No \\
\hline $\begin{array}{l}\text { South } \\
\text { meadow } \\
\text { (SM) }\end{array}$ & 34 & 1 & Relict & 3 & Mod. (3) & $\begin{array}{l}\text { Mod. frequent } \\
\text { (5) }\end{array}$ & Mod. (3) & Mod.-Heavy & No \\
\hline $\begin{array}{l}\text { Visitor center } \\
\text { (VC) }\end{array}$ & 26 & 1 & Reconstructed & 4 & Light (0) & None (NR) & Light $(3)^{\mathrm{a}}$ & Very Light & No \\
\hline
\end{tabular}

PY per year; Last YA years ago last management action of a particular type was completed, NR no record of this particular land management practice in pasture. All narrative categorizations based on mathematical indices averaging management scale, intensity, and frequency over the last 10 years. Management actions range from "None" (0/5 on intensity scale) to "Very Heavy" (5/5 on intensity scale) and from "None" (no management actions) to "Frequent" (3-year cycle or less) regarding fire. "Mod." refers to moderate. "\# Mon. plots" refers to the number of monitoring plots in a given pasture where research was conducted

${ }^{a}$ Indicates that the most recent management was not over the entire pasture

We treated haying and burning similarly, creating a 4-point scale (0-3) to summarize the spatial extent of each management action per pasture on an annual basis with " 0 " indicating "no burning" or "no haying", and " 3 " representing management affecting more than "two-thirds" of a particular pasture. We averaged these indices across 10 years for each pasture and lumped the results into the same three categories (light, moderate, or heavy) regarding haying data. Because of the importance of fire frequency to habitat management research we report the frequency of controlled burns as opposed to the intensity categories reported for haying and grazing (Table 1). A 3-year burning rotation or less is considered "frequent", a rotation of between 3 and 5 years is considered "moderately frequent", and a rotation of longer than 5 years is considered "infrequent". Additionally, the number of years ago that each management action last took place is included in the table, " 0 " represents management during the study year of 2015 (Table 1). Finally, we created an index totaling all management per pasture per year and lumped data into five categories ranging from "very light" to "very heavy." If an index score fell on the edge between two categories, for example, "moderate" and "heavy" the result was represented as "moderateheavy" (Table 1). As this data is at the pasture-level it is not included in quantitative analyses, but rather informs our general investigation into Regal habitat.
We counted butterflies using linear walking transects adapted from the methods of Swengel (1996) and Pollard (1977). During plot visits, butterfly surveys were conducted by two research personnel; the observer spotted butterfly species of concern, while the recorder utilized a GPS and a compass to navigate the monitoring transect, recorded data, and aided in the detection of butterflies. "We counted butterflies observed ahead and to the sides to the limit at which a species could be identified with binoculars" (Swengel 1996). Detections were recorded as within $10 \mathrm{~m}$ of the transect or outside of this area. Monarch and Regal detections were also recorded on the walk to and from biological monitoring plots. All Monarch and Regal sightings were recorded via GPS. All sightings within $200 \mathrm{~m}$ of the start of monitoring transects were included in the analysis. Polygons, delineating the various ecotopes that monitoring transects were meant to sample, all exceeded $200 \mathrm{~m}$ in radius within the study area. Therefore, we are confident that the vegetative community and soil profiles captured by monitoring surveys are representative of the habitat included within a $200 \mathrm{~m}$ buffer of monitoring plots. Butterfly surveys were conducted in conjunction with additional biological monitoring work. Butterfly surveys were the focus of the return walk from completing vegetation, avian, or small mammal surveys (200 m in length). Surveys lasted 15 min minimally, but could be extended to accommodate 
the presence of several butterflies to ensure proper documentation and thorough counts. Surveys were only conducted during favorable weather conditions (sunny, wind under $10 \mathrm{mph}$ ) between the late morning (10:00 am) and the midafternoon $(4: 00 \mathrm{pm})$. All plots were visited at least three times during the Regals' active time period, from June 15th to September 15th, and at least once during peak Regal activity, from June 15th to August 1st, based on the timing of Regal activity demonstrated from previous work conducted in the region (Helzer and Jasnowski 2011). Monitoring plots of particular biological interest (i.e. Henslow's Sparrow, Ammodramus henslowii use plots) were visited more frequently and thus were surveyed more often for butterflies (plot visits ranged from three to seven during the Regals' active period). Every effort was made to count individual butterflies only one time. As sampling efforts per monitoring plot were not equal we simply conduct this analysis based on the presence/absence of multiple Regals per monitoring plot. If Regal identification was questioned a picture was taken as a voucher and verified later by multiple staff. We summarize vegetation survey data, soils and flood frequency data, and land management history on a subset of the monitoring plots (17) in and around a historically persistent population of Regals to get a better understanding of where and under what management conditions Regals persist and specifically what habitats they are utilizing along the Big Bend of the Platte River, NE.

Two primary vegetation monitoring techniques were employed; the point-line intercept method and the quadrat ocular cover estimation method. Each method was utilized because they excel at collecting different types of data, though they overlap in the information they provide about an area. The point-line intercept method quickly detects dominant plant species cover and ground cover, but is not as robust at collecting species richness data (Symstad et al. 2008; Herrick et al. 2009). The quadrat ocular cover estimation method consistently detects more species, but results in more variation between observers in percent cover estimates (Symstad et al. 2008). However, with proper calibration between observers, which we completed, standardization is possible (Symstad et al. 2008). Forb species richness is of particular interest in terms of modeling butterfly habitat (Davis et al. 2007). Thus, we utilize both data sets for each monitoring plot in constructing variables relevant to Regal habitat. Vegetation monitoring for Regal study sites was conducted between mid-June and mid-August for all plots, and total species surveys were conducted. Over $90 \%$ of plants were identified to the species level, the rest were identified to genus. Both the quadrat and point-line intercept vegetation data was collected along permanently marked $100 \mathrm{~m}$ long transects which run parallel (10 m to the left) of $200 \mathrm{~m}$ long wildlife monitoring transects that include Regal surveys. This was done to reduce the impact of foot traffic on vegetation monitoring transects. Every $2 \mathrm{~m}$, starting at the $0.5 \mathrm{-m}$ mark, vegetation was recorded by placing a pin flag straight down from the tape measure. The dominant species intersecting the pin flag was recorded at each of the following height categories: short grass/forb, $\mathrm{x}<0.5 \mathrm{~m}$, tallgrass/shrub, $0.5<\mathrm{x}<2 \mathrm{~m}$ (includes grasses over $2 \mathrm{~m}$ ), and subcanopy/ canopy $2 \mathrm{~m}<\mathrm{x}$ (woody species only) (SODN-NPS 2012). Along with the dominant plant within each of the three height categories we recorded ground cover data. For the purposes of this study we lump all observations into two categories- litter and duff (includes senesced plant materials) or bare ground (rock of various sizes and bare soil). Quadrat data was recorded using a $0.5 \mathrm{~m} \times 1.0 \mathrm{~m}$ quadrat, marked in $10 \mathrm{~cm}$ increments on the quadrat frame, to aid in the estimation of cover. Cover estimations were made in increments of $5 \%$, a modification of methods by Daubenmire (1959), Symstad et al. (2008), and Muldavin and Collins (1999). The $0.5 \mathrm{~m}$ by $1 \mathrm{~m}$ quadrat was placed and interpreted every $10 \mathrm{~m}$, starting at meter 5 and continuing to meter 95 along the same monitoring transect as point-line intercept data for a total of 10 quadrats. Soil data was gathered from the USDA-NRCS (2015) and confirmed on plot, while land use history data was determined via Crane Trust internal documentation and aerial imagery.

\section{Variable construction}

Active Regal populations (REFR) were defined as those with four or more Regals detected within $200 \mathrm{~m}$ of the start of a monitoring transect (See Appendices 1a and $1 \mathrm{~b}$ in Supplemental Electronic Material). One monitoring plot had one detection of a Regal that was deemed a dispersal (plot PD2; Appendix 1c in Supplemental Electronic Material). This case was included in linear and advanced analyses, but omitted from two sample comparisons of plots with and without Regals. Sorting detections in this manner provided 16 observations $(n=16)$ for comparative analyses and 17 observations $(\mathrm{n}=17)$ for our Pearson's correlation and Random Forest analyses.

The total number of vegetative species was recorded including detections from both vegetation survey methods. This yielded a measure of total species richness (TSR). Species were categorized by growth habit using the USDANRCS's (2016) classification system to further categorize species richness measures. This generated the variables for forb species richness (FSR) (includes subshrubs), graminoid species richness (GSR), and shrub species richness (SSR). All species of vascular plants on the monitoring transects were placed into one of these categories. Average cover per quadrat was utilized to create a measure of relative cover for each species and growth habit class yielding the variables of total species cover (TSC), graminoid 
species cover (GSC), forb species cover (FSC), and shrub species cover (SSC), respectively relating to the previously constructed species richness variables. Dominant species of interest and species of theoretical importance to Regals were included along with their percent cover in the model Andropogon gerardii (ANDG), Panicum virgatum (PANV), and Viola sororia (VIOS). V. sororia was the only species of violet (Viola spp.) detected on our monitoring surveys. V. sororia was coded as a presence/absence variable $(1,0)$ on each monitoring plot due to its generally low cover when present. For each monitoring plot the top three dominant plants species of each growth habit (graminoid, forb, and shrub) were identified by averaging percent cover between both data collection methods and all three height cover classes. A wetland indicator status was assigned to each of the three dominant plants per growth habit (graminoid, forb, and shrub) for each monitoring plot when applicable (Reed 1988; Table 2). The wetland indicator status was then compared between plots with and without Regals. Plants listed as Facultative (FAC), Facultative Wetland (FACW), and Obligate Wetland (OBL) were considered "mesic" indicators and plants listed as Facultative Upland (FACU) and Obligate Upland (UPL) were considered "upland" indicators (Table 2). As FAC plants are equally likely to be within or outside of wetlands we also created the wetland plant (WP) variable. Monitoring plots with either a dominant OBL or FACW plant species were coded as a 1 and plots without a dominant wetland plant are coded as 0 . Structural cover was recorded using pointline intercept data giving a total percent cover per height class. Percent litter and duff (LD) and bare ground were totaled for each monitoring plot using the point-line intercept data. A Simpson Diversity Index measure (1-D) was calculated using the squared proportion of the total cover of each individual plant species to assess species evenness and diversity on the landscape (Spellerberg and Fedor 2003). The dominant soil type of each monitoring plot was determined by an in-field confirmation of soil maps provided by the NRCS's Web Soil Survey (NRCS 2015; Table 3). It was noted that the Inavale soil series could be important to Regals during the data collection process so that soil series is treated as a presence/absence $(1,0)$ variable in analyses (Inavale Sandy Loam-ISL).

Ries and Debinski (2001) quantified the permeability of particular habitat edges for Regals and found that tree lines (linear wood lots) were $8 \%$ permeable, crop fields were $29 \%$ permeable, roads were $43 \%$ permeable, and prairie interior was $70 \%$ permeable at a distance of $0-9 \mathrm{~m}$ from an edge (Ries and Debinski 2001). We adapted this equation for application to our monitoring plot data. First, the relative permeability is divided by the permeability of prairie interior (0.70) as that is the most permeable habitat system

Table 2 Plant wetland indicator categories used in Regal habitat analyses (Adapted from Reed 1988)

\begin{tabular}{ll}
\hline Wetland indicator category & Description \\
\hline Obligate wetland (OBL) & Almost always occurs in wetlands (estimated probability $>99 \%$ ) under natural conditions \\
Facultative wetland (FACW) & Usually occurs in wetlands (estimated probability 67-99\%), but occasionally found in non-wetlands \\
Facultative (FAC) & Equally likely to occur in wetlands (estimated probability 34-66\%) or non-wetlands \\
Facultative upland (FACU) & Usually occur in non-wetlands (estimated probability 67-99\%), but occasionally found in wetlands \\
Obligate upland (UPL) & Occur almost always (estimated probability $>99 \%$ ) in non-wetlands under natural conditions \\
\hline
\end{tabular}

Table 3 Soil type and flooding frequency at monitoring plots with and without Regals

\begin{tabular}{|c|c|c|c|}
\hline Regals present & \# Mon. plots & Regals absent & \# Mon. plots \\
\hline $\begin{array}{l}\text { Inavale loamy sand } \\
3-11 \% \text { slope (very rarely flooded) }\end{array}$ & 3 & $\begin{array}{l}\text { Platte-Bolent complex } \\
\text { (occasionally flooded) }\end{array}$ & 5 \\
\hline $\begin{array}{l}\text { Platte-inavale complex } \\
0-6 \% \text { slope (occasionally flooded) }\end{array}$ & 1 & $\begin{array}{l}\text { Bolent-Calamus complex } \\
\text { (occasionally flooded) }\end{array}$ & 4 \\
\hline Bolent-Calamus complex (occasionally flooded) & 1 & $\begin{array}{l}\text { Calamus loamy fine sand (rarely } \\
\text { flooded) }\end{array}$ & 1 \\
\hline Platte-Bolent complex (occasionally flooded) & 1 & Wann loam (rarely flooded) & 1 \\
\hline Rarely flooded & $3(50 \%)$ & Rarely flooded & $2(20 \%)$ \\
\hline Occasionally flooded & $3(50 \%)$ & Occasionally flooded & $8(80 \%)$ \\
\hline
\end{tabular}

For one plot with a transitional soil type both designations are listed and marked with superscript letter "a". This explains the difference in the number of plots listed by soil type $(\mathrm{n}=17)$ and the number listed by flooding frequency $(\mathrm{n}=16)$. "Regals present" indicates monitoring plots with Regals and "Regals absent" indicates monitoring plots without Regals. "\# Mon. plots" refers to the number of monitoring plots of a given soil type in each condition (with or without Regals) 
for Regals. We are only interested in the relative differences between the permeability of various types of habitat edges. Thus, prairie interior being the most permeable was divided by itself, creating a "permeability factor" of 1 in our index $(0.70 / 0.70=1)$. Roads by contrast were $60 \%$ as permeable as prairie interior $(0.43 / 0.70=0.61-0.60)$; permeability factors were rounded to the nearest 0.05 (hundredth). We assumed that rivers and sloughs had a similar permeability to roads, $60 \%$ as permeable as interior prairie, as they both represented a change in substrate that did not include any above ground obstruction and they were both relatively linear in nature. Via this same method crop fields were $40 \%$ as permeable as interior prairie, and tree lines were $10 \%$ as permeable as interior prairie. Secondly, we measured the linear distance from each monitoring plot directly to the nearest monitoring plot with Regals via Google Earth (2015). We then measured the various proportions of that line that were composed of the various habitat edge types. Small objects in terms of width that butterflies could reasonably fly around were not considered in the permeability portion of the analysis. We considered a good estimate of the isolation of Regal monitoring plots from each other to be: distance/permeability=isolation. A low isolation score indicates proximity and permeability whereas a high isolation score indicates distance and obstruction to movement between a given monitoring plot and the nearest monitoring plot with Regals. Therefore, we expect Isolation (ISO) to be negatively associated with Regal presence (REFR). The final equation is as follows ( $\mathrm{D}=$ distance and $\mathrm{P}=$ permeability):

$$
\begin{aligned}
& \text { (D-prairie/P-prairie })+(\text { D-river/P-river }) \\
& \quad+(\text { D-road/P-road })+(\text { D-crop/P-crop }) \\
& \quad+(\text { D-tree line/P-tree line })=\text { Isolation }(\text { ISO })
\end{aligned}
$$

All plots were coded as reconstructed (0), restored (1), or relict (2) in constructing the variable RRR. A "relict" plot had never been tilled, planted with non-native species, been allowed to become a different system (forest), or been over-utilized to the degree that a majority of relict components (dominant native grasses and forbs) were absent. "Restored" prairie was defined as a system that at one time had been planted with non-native species for livestock forage, intensively managed to the degree it lacked a majority of relict components (used as a calving pasture and grazed to bare ground frequently), or was allowed to become forest/woodland, and subsequent efforts had been taken to restore it to native prairie (i.e. Phalaris arundinacea, an invasive non-native species, historically planted for pasture and subsequently controlled in later conservation efforts). Restored prairie here may have been seeded, but never tilled. Finally, "reconstructed" prairie was defined as having been intensively tilled, used as agricultural land, and subsequently seeded and replanted with native prairie species suspected to have inhabited that area in the past. A summary of all monitoring plot-level variables and their corresponding shorthand codes are presented in Table 4 .

\section{Data analysis}

We analyzed our data in a three-step process. First, we used comparative statistics for two independent samples to look at the differences between plots with and without Regals. We used Chi-squared tests $\left(\chi^{2}\right)$ to compare the frequency of categorical variables between the two samples and twotailed independent sample $t$ tests assuming equal variance to compare between the means of continuous variables for their respective samples (Tables 5, 6). We utilized the open source statistics software "R" to compare the variance between our two samples (with and without Regals) before conducting $t$ tests to assure the appropriate application of that particular analysis (R Core Team 2015). We also included an investigation of the dominant plant species in our analysis (Table 7). Secondly, we conducted a Pearson's correlation analysis (R package "performance analytics") to examine the correlations (continuous) and associations (binary and factor) of all variables with plots having multiple Regals (REFR) (R Core Team 2015). We also examined the correlations and associations between variables to get a better picture of Regal habitat (Table 8).

Third, we performed a random forest analysis (RFA), which is a form of "ensemble" or "machine learning" that creates many permutations of classification trees and compiles the results (Breiman 2001; Liaw and Wiener 2002). RFA is adept at dealing with highly significant variables in a dataset with a small number of cases and also deals well with correlated variables. RFA uses "bootstrap sampling," which randomly samples a set number of variables with replacement from a dataset in order to predict a particular outcome (Liaw and Wiener 2002; Breiman 2001). RFA has the ability to rank variables in terms of importance by displaying the mean decrease in accuracy resulting from the removal of a particular variable from the model (Breiman 2001). This analysis accurately accounts for complex non-linear relationships in ecological data (Cutler et al. 2007). We utilized the "Random Forest" package in R to complete this analysis using 5000 classification trees constructed from randomly selected sets of variables from our dataset (bootstrapping) with two variables tried at each split (Fig. 2; R Core Team 2015). First, we examine the mean decrease in accuracy of predicting the dependent variable (REFR) when particular variables are removed. The variables that reduce model accuracy the most on average when removed are considered the most important. Secondly, the mean decrease in the Gini index assesses the homogeneity of the data. RFA works by splitting the data at various 
Table 4 Codes, names, and descriptions of monitoring plot-level variables utilized in Regal habitat analyses

\begin{tabular}{|c|c|c|}
\hline Code & Variable Name & Description \\
\hline ISO & Isolation score & Measure of isolation of monitoring plot from nearest regal population $(0-\infty)$ \\
\hline RRR & Relict, restored, reconstructed & Land use history of monitoring plot—relict (2), restored (1), reconstructed (0) \\
\hline TSR & Total species richness & Total number of vascular plant species on monitoring plot $(0-\infty)$ \\
\hline FSR & Forb species richness & Total number of forb growth habit species on monitoring plot $(0-\infty)$ \\
\hline $\mathrm{GSR}^{\mathrm{a}}$ & Graminoid species richness & Total number of graminoid growth habit species on monitoring plot $(0-\infty)$ \\
\hline SSR & Shrub species richness & Total number of shrub growth habit species on monitoring plot $(0-\infty)$ \\
\hline $\mathrm{TSC}^{\mathrm{a}}$ & Total species cover & Total percent cover of vascular plant species on monitoring plot $(0-\infty)$ \\
\hline $\mathrm{GSC}^{\mathrm{a}}$ & Graminoid species cover & Total percent cover of all graminoid growth habit species on monitoring plot $(0-\infty)$ \\
\hline FC & Forb cover & Total percent cover of all forb growth habit species on monitoring plot $(0-\infty)$ \\
\hline $\mathrm{SC}$ & Shrub cover & Total percent cover of all shrub growth habit species on monitoring plot $(0-\infty)$ \\
\hline SDI & Simpson Diversity Index (1-D) & Measure assesses species evenness and diversity on monitoring plot $(0-1)$ \\
\hline PE & Percent exotic cover & Total percent cover of all exotic invasive species from monitoring plot $(0-\infty)$ \\
\hline ANDG & Andropogon gerardii cover & A. gerardii percent cover on monitoring plot $(0-\infty)$ \\
\hline PANV & Panicum virgatum cover & $P$. virgatum percent cover on monitoring plot $(0-\infty)$ \\
\hline VIOS & Viola sororia present & V. sororia present on monitoring plot $(1,0)$ \\
\hline WP & Wetland plant & Monitoring plots with a wetland plant (FACW, OBL) as dominant $(1,0)$ \\
\hline $\mathrm{C} 2 \mathrm{M}$ & Woody cover above $2 \mathrm{~m}$ & Percent woody structural cover above $2 \mathrm{~m}$ in height (shrubs and trees only) $(0-100 \%)$ \\
\hline LD & Litter/duff & Percent ground cover as litter and duff $(0-100 \%)$ \\
\hline ISL & Inavale sandy loam & Inavale series soils present on monitoring plot $(1,0)$ \\
\hline REFR & Regals present & Monitoring plots having multiple Regal detections $(1,0)$ \\
\hline
\end{tabular}

${ }^{a}$ Indicates that variables were included in comparative analyses, but dropped from Pearson's correlation analysis and random forest analysis. " $(0-\infty)$ " refers to continuous or count variables with theoretically no upper limit (includes species cover variables from quadrat data that include overlapping cover and can theoretically exceed $100 \%$ cover $)$ " "(1, 0)" refers to a binary variable. "(0-100\%)" refers to cover data from point-line intercept method, which is limited between 0 and $100 \%$

Table 5 Comparison of categorical variables between monitoring plots with and without Regals

\begin{tabular}{|c|c|c|c|c|c|}
\hline Variable & Category & REFR & No REFR & $\chi^{2}$ & $p$ value \\
\hline \multirow[t]{2}{*}{ Land use } & Relict & 6 & 5 & 4.36 & $0.037 *$ \\
\hline & Restored or reconstructed & 0 & 5 & & \\
\hline \multirow[t]{2}{*}{ Graminoid (dominants) } & Upland & 13 & 17 & 3.12 & $0.078^{\wedge}$ \\
\hline & Mesic & 2 & 11 & & \\
\hline \multirow[t]{2}{*}{ Forb (dominants) } & Upland & 12 & 17 & 0.39 & 0.53 \\
\hline & Mesic & 2 & 5 & & \\
\hline \multirow[t]{2}{*}{ Andropogon gerardii } & Dominant & 6 & 5 & 4.36 & $0.037 *$ \\
\hline & Not Dom. & 0 & 5 & & \\
\hline \multirow[t]{2}{*}{ Panicum virgatum } & Dominant & 1 & 5 & 1.78 & 0.18 \\
\hline & Not Dom. & 5 & 5 & & \\
\hline \multirow[t]{2}{*}{ Flooding } & Rare & 3 & 2 & 1.57 & 0.21 \\
\hline & Occasional & 3 & 8 & & \\
\hline \multirow[t]{2}{*}{ Soils } & Inavale series & 4 & 0 & 8.89 & $0.002 * *$ \\
\hline & Other & 2 & 10 & & \\
\hline \multirow[t]{2}{*}{ Viola sororia } & Present & 6 & 1 & 12.34 & $0.0004 * * *$ \\
\hline & Absent & 0 & 9 & & \\
\hline
\end{tabular}

"REFR" refers to monitoring plots with Regals and "No REFR" refers to monitoring plots without Regals. The unit of measure is monitoring plots $(\mathrm{n}=16)$ in all cases except regarding "Graminoid (dominants)" and "Forb (dominants)", which refers to the number of dominant vascular plant species of each growth habit (Graminoids, Forbs) with "Upland" or "Mesic" wetland indicator statuses (Reed 1988) recorded at monitoring plots. Dominant forbs and graminoids not designated a wetland indicator status in Reed (1988) are dropped from the analysis

$\hat{p}<<0.10, * p<0.05, * * p<0.01, * * * p<0.001$ 
Table 6 Comparison of continuous variables between monitoring plots with and without Regals

\begin{tabular}{|c|c|c|c|c|c|}
\hline Variable & Category & $\begin{array}{l}\text { REFR } \\
\text { M (SD) }\end{array}$ & $\begin{array}{l}\text { No REFR } \\
\text { M (SD) }\end{array}$ & $t$-statistic & $\begin{array}{l}p \text { value } \\
\text { (2-tailed) }\end{array}$ \\
\hline \multirow[t]{4}{*}{ Species richness } & Graminoid & $16.0(4.3)$ & $13.6(3.9)$ & 1.151 & 0.269 \\
\hline & Forb & $14.5(1.9)$ & $9.7(2.8)$ & 3.699 & $0.002 * *$ \\
\hline & Shrub & $0.0(0.0)$ & $1.3(2.1)$ & -1.526 & $0.149^{\sim}$ \\
\hline & Total & $30.17(5.0)$ & $24.6(3.7)$ & 2.565 & $0.022 *$ \\
\hline Simpson Diversity Index (1-D) & & $0.869(0.053)$ & $0.855(0.063)$ & 0.423 & 0.339 \\
\hline \multirow[t]{4}{*}{ Percent cover } & Graminoid & $118.7(12.6)$ & $122.0(21.1)$ & -0.352 & 0.729 \\
\hline & Forb & $46.0(6.1)$ & $31.8(8.9)$ & 3.439 & $0.004 * *$ \\
\hline & Shrub & $0.0(0.0)$ & 9.7 (25.7) & -0.906 & 0.380 \\
\hline & Total & $164.7(16.0)$ & $163.3(37.1)$ & 0.084 & 0.935 \\
\hline Percent exotic cover & & $24.7(10.3)$ & $27.6(19.7)$ & -0.333 & 0.744 \\
\hline Percent cover A. gerardii & & $43.6(13.3)$ & $22.0(24.1)$ & 2.001 & $0.064^{\wedge}$ \\
\hline Percent cover $P$. virgatum & & $6.3(3.9)$ & $15.1(14.5)$ & -1.449 & $0.169^{\sim}$ \\
\hline \multirow[t]{3}{*}{ Structural cover } & $0-0.5 \mathrm{~m}$ & $100(0.0)$ & $99.4(1.0)$ & 1.5 & 0.156 \\
\hline & $0.5-2.0 \mathrm{~m}$ & $96.0(3.3)$ & $87.6(21.5)$ & 0.936 & 0.365 \\
\hline & $2.0 \mathrm{~m}+$ & $0(0.0)$ & $1.2(2.5)$ & -1.146 & 0.271 \\
\hline \multirow[t]{2}{*}{ Ground cover } & Litter & $92(6.9)$ & $76.6(18.3)$ & 1.97 & $0.069^{\wedge}$ \\
\hline & Bare ground & $8(-)$ & $23.4(-)$ & & \\
\hline Isolation score & & $575.83(434.10)$ & $1337(710.45)$ & -2.355 & $0.033^{*}$ \\
\hline
\end{tabular}

"REFR" refers to monitoring plots with Regals and "No REFR" refers to monitoring plots without Regals. "M" refers to mean and "SD" to standard deviation. "Percent exotic cover" is the sum of invasive exotic plant species cover at each monitoring plot. "Structural cover" is the total vegetative cover $(0-100 \%)$ per height class of vegetation. The "Isolation score" represents the distance of a given monitoring plot to the nearest monitoring plot with Regals divided by the permeability of the path between them. To produce $p$ values for 1-tailed $t$ tests divide the 2-tailed $t$ test $p$ values presented in the table by two.

${ }^{\wedge} p<0.10, * p<0.05, * * p<0.01, * * * p<0.001$

$\tilde{p}<0.10$ given a 1 -tailed $t$ test justified by directional hypotheses nodes (independent variables in the analysis) and is complete when further splitting no longer results in a mean decrease of the Gini index. The Gini index becomes lower as predictor variable subgroups become more homogenous (Breiman 2001; Cutler et al. 2007). Therefore as particular variables are removed the data becomes less homogenous. We utilized partial dependence plots ("interpret R" package; R Core Team 2015) to visualize the relationship between the independent variables and presence of Regals (REFR; Fig. 3), as they are very useful for visualizing nonlinear relationships. As the negative number along the y-axis approaches 0 (ascending vertically) the likelihood of Regal presence increases and as the number along the $y$-axis becomes more negative (descending vertically) approaching -1.0 the probability of Regal presence decreases. We select a number of important variables from the analysis and plot them along with Regal presence to better explore our data. Finally, we designed a pathway model that theoretically and visually describes the habitat variables that we used to predict Regal occurrence and suggests future directions regarding habitat management research for Regals (Fig. 4).

\section{Results}

Surveyors detected 677 Monarchs and 56 Regals. Generally, we have high resolution, high quality data, with limited statistical power resulting from a limited number of cases $(n=17)$. Following Fay and Gerow (2013) we include $p$ values between 0.05 and 0.10 to indicate marginal statistical significance.

\section{Analysis of categorical variables}

Categorical variables were compared between plots with and without Regals (Table 5). We found that plots with Regals were more likely to be relict compared to restored (includes both restored and reconstructed) $(p=0.037)$. Regals were present only on relict plots; however, $50 \%$ of the plots without Regals were also relict. When plants were divided into "upland" and "mesic" indicator communities, plots with Regals were marginally more likely to be characterized by upland graminoid species $(p=0.078)$, in particular facultative upland (FACU) species $(86.67 \%$ of dominant graminoids on plots with Regals vs. $57.14 \%$ on plots without). The same trend was not detected for forb species. $A$. 
Table 7 Dominant plant species by growth habit, plant code, scientific name, wetland indicator status, and the percent of monitoring plots with and without Regals they are dominant

\begin{tabular}{|c|c|c|c|c|c|c|c|c|c|}
\hline \multirow[t]{2}{*}{ Plant code } & \multicolumn{4}{|l|}{ Graminoids } & \multirow[t]{2}{*}{ Plant code } & \multicolumn{4}{|l|}{ Forbs/shrubs } \\
\hline & Scientific name & $\begin{array}{l}\text { Wetland } \\
\text { indicator }\end{array}$ & $\begin{array}{l}\text { With Regals } \\
(\%)\end{array}$ & $\begin{array}{l}\text { With- } \\
\text { outRe- } \\
\text { gals (\%) }\end{array}$ & & $\begin{array}{l}\text { Scientific } \\
\text { name }\end{array}$ & $\begin{array}{l}\text { Wetland } \\
\text { indicator }\end{array}$ & $\begin{array}{l}\text { With Regals } \\
(\%)\end{array}$ & $\begin{array}{l}\text { Without } \\
\text { Regals } \\
(\%)\end{array}$ \\
\hline ANDGER & $\begin{array}{c}\text { Andropogon } \\
\text { gerardii }^{\mathrm{a}}\end{array}$ & FACU & 100.0 & 50.0 & AMBPSI & $\begin{array}{l}\text { Ambrosia } \\
\quad \text { psilostachya }\end{array}$ & FACU & 83.3 & 50.0 \\
\hline POAPRA & Poa pratensis ${ }^{\mathrm{b}}$ & FACU & 83.3 & 50.0 & SYMERI & $\begin{array}{l}\text { Symphyotri- } \\
\text { chum } \\
\text { ericoides }\end{array}$ & FACU & 66.7 & 40.0 \\
\hline PANOLI & $\begin{array}{l}\text { Panicum oli- } \\
\text { gosanthes }\end{array}$ & NA & 50.0 & 0.0 & CALINV & $\begin{array}{l}\text { Callirhoe } \\
\text { involucrata }^{\mathrm{a}}\end{array}$ & NA & 50.0 & 10.0 \\
\hline PANVIR & $\begin{array}{l}\text { Panicum virga- } \\
\text { tum }^{\mathrm{a}}\end{array}$ & FAC & 16.7 & 50.0 & VIOSOR & Viola sororia $^{\mathrm{a}}$ & FAC & 33.3 & 0.0 \\
\hline SCHSCO & $\begin{array}{l}\text { Schizachyrium } \\
\text { scoparium }\end{array}$ & FACU & 16.7 & 0.0 & GLYLEP & $\begin{array}{c}\text { Glycyrrhiza } \\
\text { lepidota }\end{array}$ & FACU & 16.7 & 0.0 \\
\hline AGRSTO & $\begin{array}{l}\text { Agrostis stolonif- } \\
\text { era }^{\mathrm{b}}\end{array}$ & FACW & 16.7 & 0.0 & VERSTR & $\begin{array}{r}\text { Verbena } \\
\text { stricta }\end{array}$ & NA & 16.7 & 10.0 \\
\hline SORNUT & $\begin{array}{l}\text { Sorghastrum } \\
\text { nutans }\end{array}$ & FACU & 0.0 & 20.0 & MEDLUP & $\begin{array}{l}\text { Medicago } \\
\text { lupulina }^{\mathrm{b}}\end{array}$ & FACU & 16.7 & 10.0 \\
\hline SPAPEC & $\begin{array}{l}\text { Spartina pecti- } \\
\qquad \text { nata }^{\mathrm{a}}\end{array}$ & FACW & 0.0 & 20.0 & SYMOCC & $\begin{array}{l}\text { Symphori- } \\
\quad \text { carpos } \\
\text { occidentlis }^{\mathrm{a}}\end{array}$ & UPL & 16.7 & 20.0 \\
\hline BROINE & $\begin{array}{l}\text { Bromus } \\
\quad \text { inermis }^{\mathrm{a}, \mathrm{b}}\end{array}$ & FACU & 0.0 & 10.0 & CORDRU & $\begin{array}{l}\text { Cornus drum- } \\
\text { mondii }^{\mathrm{a}}\end{array}$ & FAC & 0.0 & 10.0 \\
\hline BROTEC & $\begin{array}{l}\text { Bromus } \\
\text { tectorum }^{\mathrm{a}, \mathrm{b}}\end{array}$ & NA & 0.0 & 10.0 & ACHMIL & $\begin{array}{l}\text { Achillea } \\
\quad \text { millefolium }\end{array}$ & FACU & 0.0 & 10.0 \\
\hline PHAARU & $\begin{array}{l}\text { Phalaris } \\
\quad \text { arundinacea }^{\mathrm{a}, \mathrm{b}}\end{array}$ & FACW & 0.0 & 10.0 & RHUGLA & Rhus glabra & NA & 0.0 & 10.0 \\
\hline ELYCAN & $\begin{array}{l}\text { Elymus canaden- } \\
\text { sis }\end{array}$ & FACU & 0.0 & 10.0 & HELPAU & $\begin{array}{l}\text { Helianthus } \\
\text { pauciflorus }\end{array}$ & NA & 0.0 & 10.0 \\
\hline$N A$ & $\begin{array}{l}\text { Schedonorus } \\
\text { spp. }{ }^{\mathrm{a}, \mathrm{b}}\end{array}$ & FACU & 0.0 & 30.0 & MONFIS & $\begin{array}{l}\text { Monarda } \\
\text { fistulosa }\end{array}$ & UPL & 0.0 & 10.0 \\
\hline$N A$ & Eleocharis spp. $^{\text {a }}$ & FACW & 0.0 & 20.0 & SOLRIG & $\begin{array}{l}\text { Solidago } \\
\text { rigida }\end{array}$ & NA & 0.0 & 10.0 \\
\hline \multirow[t]{9}{*}{$N A$} & Carex spp. ${ }^{\text {a }}$ & FACW & 0.0 & 20.0 & SOLMIS & $\begin{array}{l}\text { Solidago mis- } \\
\text { souriensis }\end{array}$ & NA & 0.0 & 10.0 \\
\hline & & & & & DESILL & $\begin{array}{c}\text { Desmanthus } \\
\text { illinoensis }\end{array}$ & FACU & 0.0 & 10.0 \\
\hline & & & & & MELALB & $\begin{array}{l}\text { Melilotus } \\
\text { albus }^{\mathrm{b}}\end{array}$ & FACU & 0.0 & 10.0 \\
\hline & & & & & PHYLAN & $\begin{array}{l}\text { Phyla lanceo- } \\
\text { lata }^{\mathrm{a}}\end{array}$ & OBL & 0.0 & 20.0 \\
\hline & & & & & APOCAN & $\begin{array}{l}\text { Apo- } \\
\text { cynum can- }^{\text {nabinium }}\end{array}$ & FAC & 0.0 & 10.0 \\
\hline & & & & & SOLCAN & $\begin{array}{l}\text { Solidago } \\
\quad \text { canadensis }\end{array}$ & FACU & 0.0 & 10.0 \\
\hline & & & & & HELPET & $\begin{array}{l}\text { Helianthus } \\
\text { petiolaris }\end{array}$ & NA & 0.0 & 10.0 \\
\hline & & & & & PLAPAT & $\begin{array}{l}\text { Plantago } \\
\text { patagonica }\end{array}$ & NA & 0.0 & 10.0 \\
\hline & & & & & VERFAS & $\begin{array}{l}\text { Vernonia fas- } \\
\text { ciculata }^{\mathrm{a}}\end{array}$ & FAC & 0.0 & 10.0 \\
\hline
\end{tabular}

Plant codes corresponding to "Appendix 1" in "Supplemental Electronic Material". Plants with superscript letter "a" denote species of interest. Plants with superscript letter " $b$ " denote exotic invasive species. Wetland indicator codes: see further Table 2 


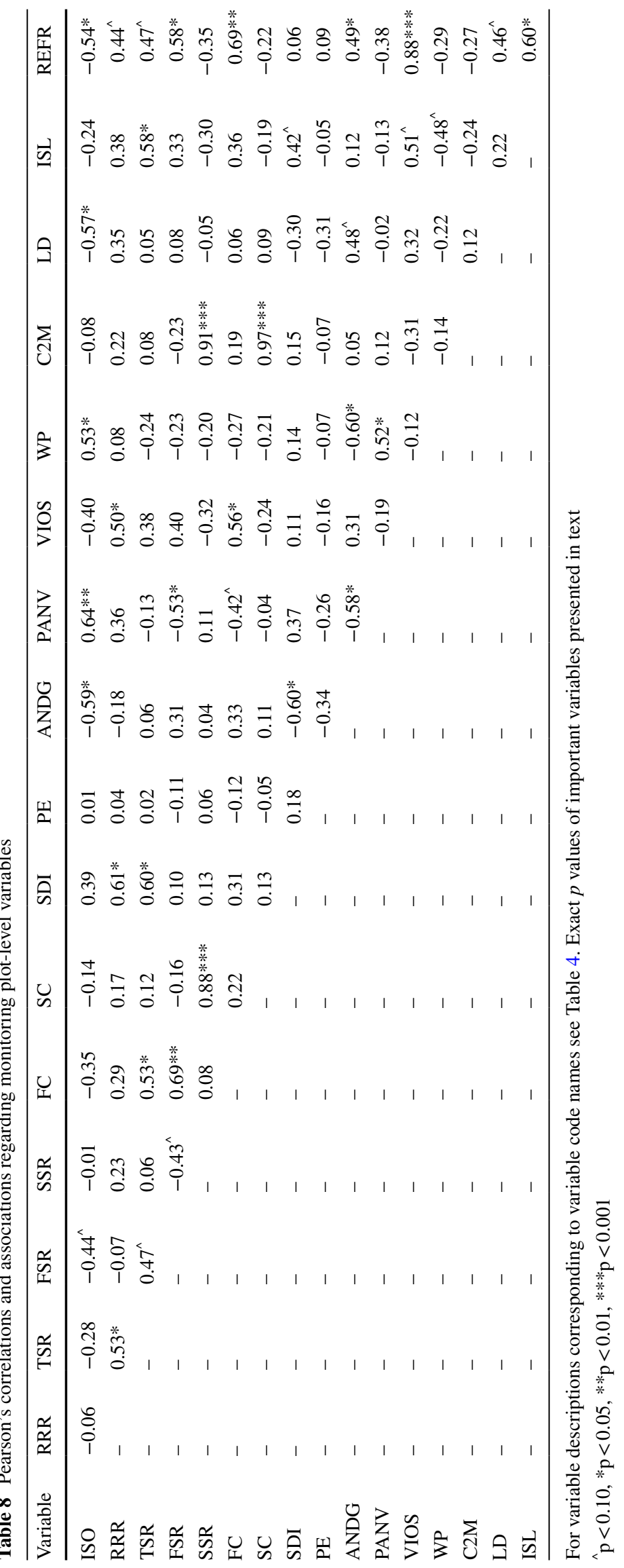


Fig. 2 Monitoring plot-level variables ranked by importance in predicting the presence of Regals utilizing random forest analysis. "Mean Decrease Accuracy" relates to the \% decrease in model accuracy when a particular variable is removed. "Mean Decrease Gini Index" relates to the decrease in the homogeneity of the data's predictive ability when a particular variable is removed. For variable descriptions corresponding to variable code names see Table 4
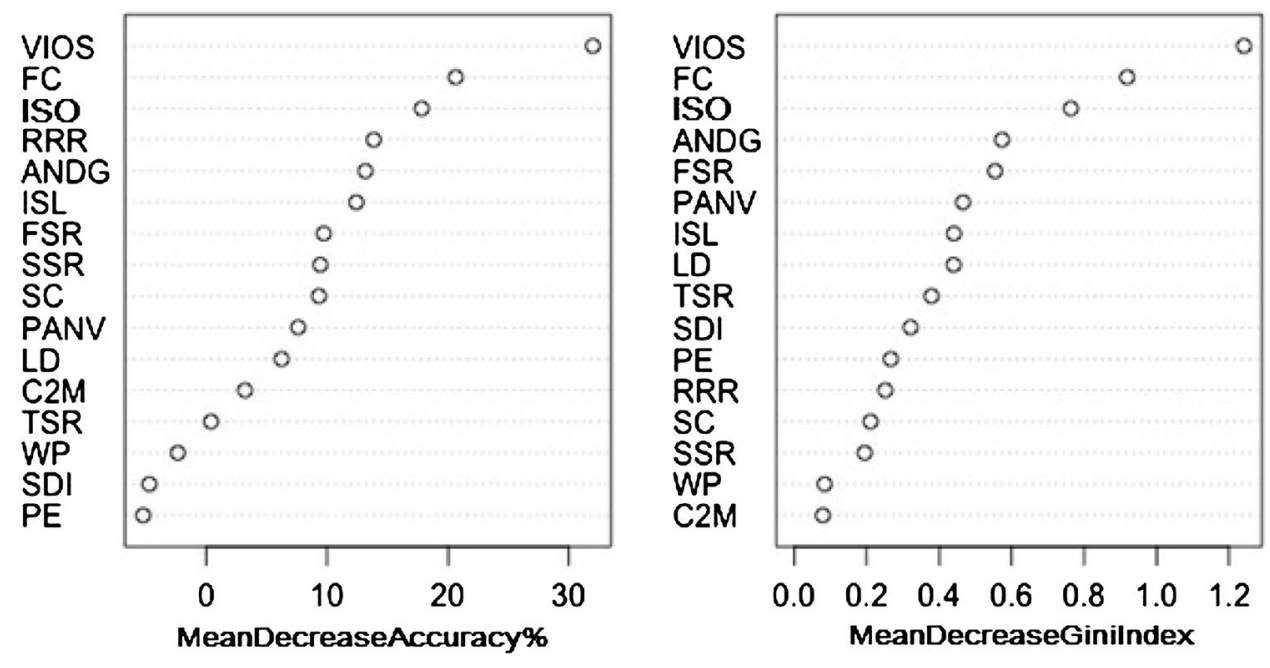
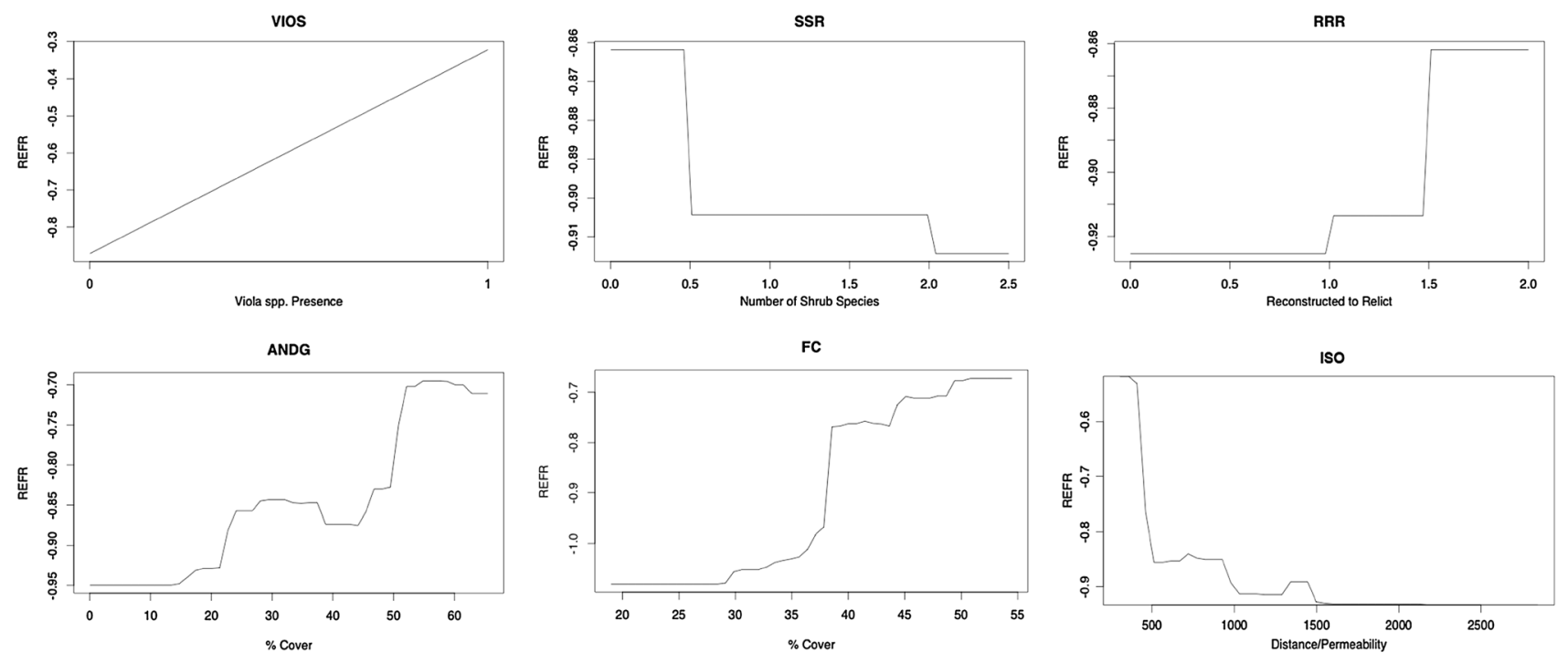

ISL
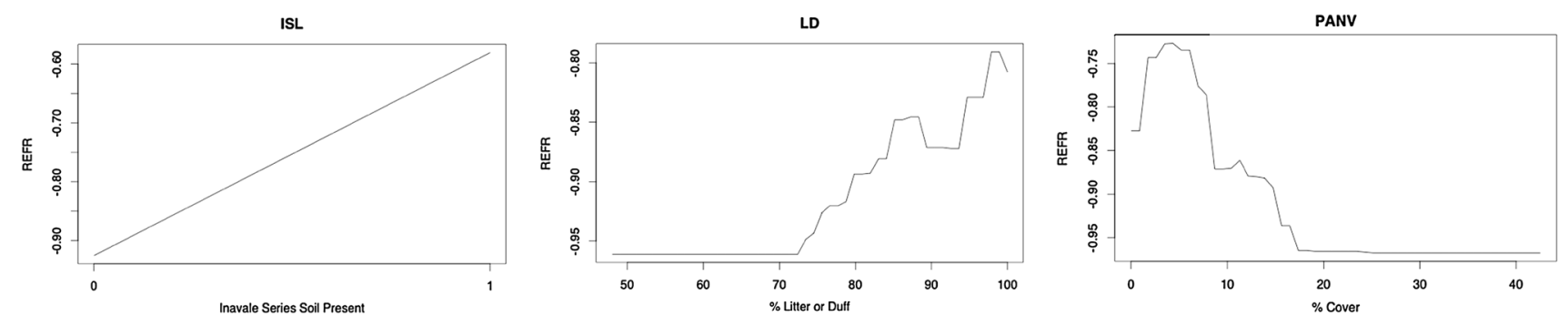

Fig. 3 Partial dependence plots: probability of Regal presence by select independent variables from random forest analysis. For variable descriptions corresponding to variable code names see Table 4

gerardii was one of the three most dominant graminoids on all plots with Regals but was only dominant on 50\% of plots without Regals $(p=0.037)$. We also examined the dominance of $P$. virgatum expecting it to be more indicative of wetter sites not preferred by the Regals. $P$. virgatum was dominant on $50 \%$ of plots without Regals and only $16.67 \%$ of plots with Regals. However, this finding was not significant $(p=0.18)$. Based on USDA-NRCS (2015) soils data $50 \%$ of plots with Regals were rarely flooded as opposed to only $20 \%$ of plots without, but this difference was not significant ( $p=0.21$; Tables 5, 3). Plots with Regals were much more likely to have Inavale series soils $(p=0.002)$. 


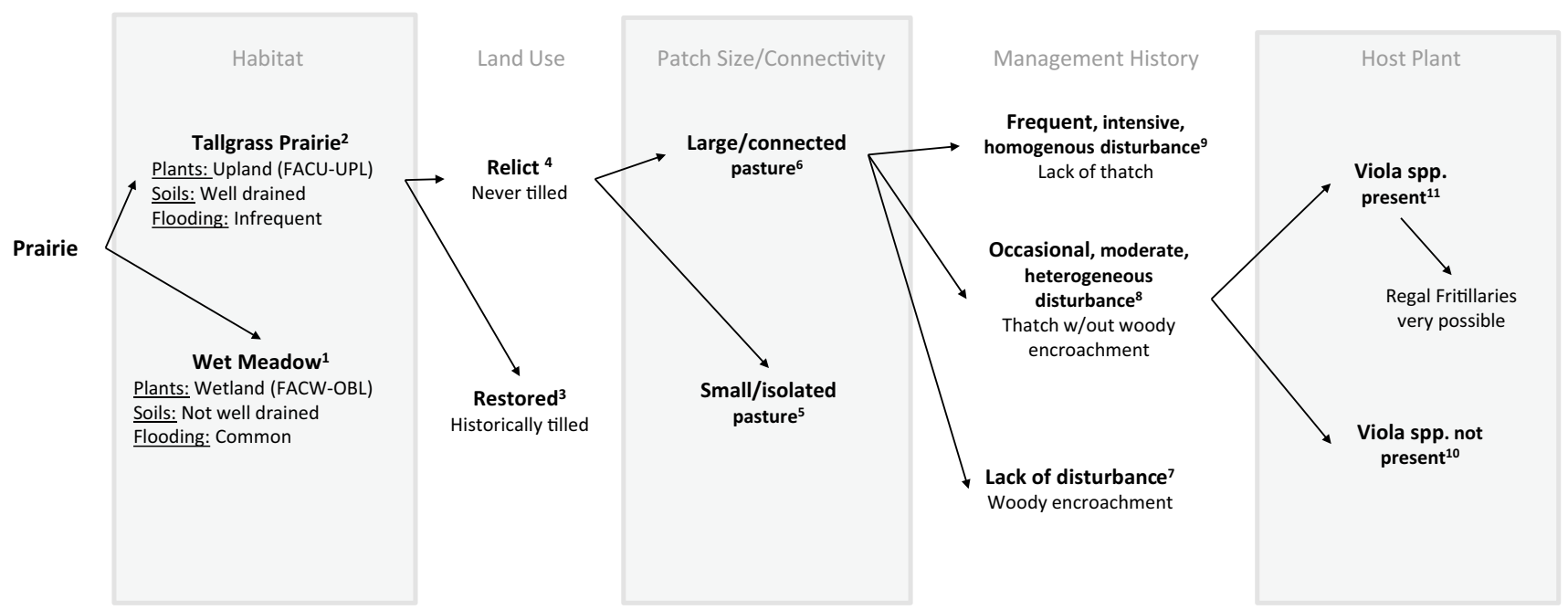

Regal habitat pathway model: associated covariates, and exemplar monitoring plot from our data

${ }^{1}$ Related Variables: WP*+, PANV+ Monitoring Plot: M1

${ }^{2}$ Related Variables: ANDG*+, ISL*+ Monitoring Plot: SB2

${ }^{3}$ Related Variables : RRR*-, SDI-, TSR-, VIOS- Monitoring Plot: Ro5

${ }^{4}$ Related Variables: RRR*+, SDI+, TSR+, VIOS+ Monitoring Plot: Ro3

${ }^{5}$ Related Variables : ISO*+ Monitoring Plot: VC1

6Related Variables: ISO*- Monitoring Plot: R1

${ }^{7}$ Related Variables: $\mathrm{C}_{2} \mathrm{M}^{*}+, \mathrm{SSR}^{*}+, \mathrm{SC}^{*}+$, FC- $\quad$ Monitoring Plot: SB1

${ }^{8}$ Related Variables: LD*+, SDI+, TSR+, FSR+, FC+ Monitoring Plot: Ro4

${ }^{9}$ Related Variables: LD*-, PE+, SDI-, TSR-, FSR- Monitoring Plot: CP1

${ }^{10}$ Related Variables: VIOS*-, RRR- Monitoring Plot: OP1

${ }^{11}$ Related Variables: VIOS*+, RRR+ Monitoring Plot: WR1

Notes: *Denotes directly related variables (direct measure of phenomenon). -/+ Denotes theoretical relation ship of covariates to the various concepts described in the habitat pathway model. Variables in Bold print show some model value in at least one statistical analysis technique- 2 sample tests, correlations, or Random Forest Analysis. Data regarding exemplar monitoring plots can be found in "Appendix 1" in "Supplemental Electronic Information." For variable descriptions corresponding to variable code names see Table 4.

Fig. 4 Regal habitat pathway model: contexts in which Regals may be present based on our data and pertinent literature

Finally, we found that $V$. sororia was much more likely to be present at plots with Regals and absent from plots without $(p=0.0004)$. $V$. sororia presence ranged from 0.5 to $6 \%$ ground cover on plots with Regals (mean $=3.0 \%$ ) and $0-0.5 \%$ on plots without Regals (mean $=0.05 \%$ ). V. sororia was only detected on one plot without Regals (M1; Appendix $1 b$ in Supplemental Electronic Material).

\section{Analysis of continuous variables}

Results of two-way independent sample $t$ tests are given in Table 6 . We report one-tailed $t$ test results in the text where directional hypotheses were used. In terms of species richness variables, both forb species richness (FSR) and total species richness (TSR) were significantly greater on plots with Regals $(p=0.002$ and $p=0.022$ respectively; see Table 4 for variable descriptions); shrub species richness (SSR) was marginally higher on plots without Regals (onetailed $t$ test, $p=0.075$ ). Forb cover (FC) was significantly higher on plots with Regals $(p=0.004)$, as was the percent cover of $A$. gerardii (ANDG) (one-tailed $t$ test, $p=0.032$ ) while $P$. virgatum (PANV) cover was marginally higher on plots without Regals (one-tailed $t$ test, $p=0.085$ ). Structural cover did not differ significantly between plots with and without Regals, but litter (LD) was significantly higher on plots with Regals (one-tailed $t$ test, $p=0.035$ ). Interestingly, woody structural cover above $2 \mathrm{~m}$ in height (C2M) and shrub cover (SC), variables indicating shrub encroachment (Table 4), did not differ between sites with and without Regals; nevertheless, no monitoring plot with Regals demonstrated any measurable shrub cover via our methods (Table 6). Finally, monitoring plots without Regals demonstrated higher mean isolation scores (ISO) than those with Regals $(p=0.033)$.

\section{Dominant vegetation}

Here we present a short synopsis of the dominant vegetation contrasting those plots with and without Regals (Table 7). Shrubs were absent from many plots and therefore were combined with forbs in our analysis. In this context shrub dominance over non-woody forbs indicates 
shrub encroachment. Graminoid species dominant at more than one plot with Regals were as follows: A. gerardii, Poa pratensis, and Panicum oligosanthes. P. pratensis is an invasive species and was common across various habitats at the Crane Trust, including areas with and without Regals (Tables 4,7). A. gerardii is a native warm season grass and was a dominant graminoid on all sites with Regals. Additionally, P. oligosanthes was present on all monitoring plots with Regals and was a dominant graminoid on $50 \%$ of those plots (Range: $1-14.5 \%$ cover). Forb species dominant at multiple plots with Regals were: Ambrosia psilostachya, Symphyotrichum ericoides, Callirhoe involucrata, and V. sororia. V. sororia was present at all plots with Regals and was a dominant forb at two of those plots. By contrast V. sororia was present, and not dominant, at only one plot $(0.5 \%$ cover $)$ without Regals. C. involucrata was present as a dominant forb at three plots with Regals and only one plot without. $A$. psilostachya and $S$. ericoides were common throughout a variety of habitats with and without Regals. Graminoid species present as dominant at more than one plot without Regals were as follows: $P$. virgatum, $P$. pratensis, $A$. gerardii, Schedonorus spp., Carex spp., Eleocharis spp., Sorghastrum nutans, and Spartina pectinata. Of these eight species/genera, five were not dominant on any plots with Regals, and the most frequently dominant species on plots without Regals, P. virgatum, was dominant on only one site with Regals. Forb/shrub species dominant at more than one plot without Regals include: Ambrosia psilostachya, Symphyotrichum ericoides, Phyla lanceolata, and Symphoricarpos occidentals. P. lanceolata is not dominant on any sites with Regals and is dominant on two without; it is also a wetland indicator species (OBL).

\section{Correlation analysis}

We utilized a set of 17 variables (Table 4) to examine what habitat factors are associated with the presence of multiple Regals (REFR) using Pearson's correlations (Table 8). The strongest association $(\mathrm{r}=0.88, p=0.000003)$ with the presence of Regals was the presence of their larval host plant $V$. sororia (VIOS). Our constructed measure of isolation (ISO) was negatively associated with REFR $(p=0.026)$. We found a marginally positive relationship between our constructed measure of relict, restored, and reconstructed (RRR) prairies and REFR $(p=0.077)$; denoting that prairies coded as "relict" are positively associated with Regals. Total species richness (TSR) had a marginally positive association with Regal presence $(p=0.055)$. However, Forb species richness (FSR) had a stronger and more significant association with REFR $(p=0.015)$ than TSR. Forb cover (FC) showed a stronger association than either species richness measure with Regal presence $(p=0.002)$. Not surprisingly, FC and FSR were positively correlated $(p=0.002)$. No measure of shrub encroachment was significantly correlated with Regals. The percent cover of $A$. gerardii (ANDG) was positively associated with REFR $(p=0.047)$ and was also marginally positively correlated with litter cover (LD); the latter was, itself, marginally positively associated with REFR $(p=0.065)$.The Inavale series soil type (ISL) was positively associated with REFR $(p=0.010)$. No relationship between the cover of $P$. virgatum (PANV) and Regals was identified; however, PANV was positively associated with a dominant wetland indicator plant species (WP) $(p=0.031)$ which was itself negatively associated with ANDG $(p=0.011)$.

\section{Random forest analysis}

The out of bag (OOB) error estimate was 5.88\%. A confusion matrix demonstrated that the random forest analysis (RFA) correctly predicted the absence of Regals in 11/11 cases with an error rate of $0.00(0 \%)$. RFA correctly predicted the presence of Regals in 5/6 cases with an error rate of $0.1667(16.67 \%)$. Variables are assessed in two ways using RFA, a mean decrease in model accuracy and mean decrease in the Gini index. The top three variables of importance were the same via both measures in our study. These variables were VIOS (V. sororia presence), FC (\% forb cover), and Isolation (ISO) respectively (Fig. 2). ANDG (\% A. gerardii cover) was also one of the top five variables of importance by both measures. Variables near or below 0 (their presence actually makes the model worse) regarding mean decrease in model accuracy were PE (percent exotic species), SDI (Simpson Diversity Index), wetland plant (WP), and total species richness (TSR). The rest of the variables demonstrate a mean decrease in accuracy of between about $4 \%(\mathrm{C} 2 \mathrm{M})$ and $33 \%$ (VIOS) when removed from the model. WP was the only variable in the bottom three by both measures (mean decrease in accuracy and mean decrease in the Gini Index). The variables of RRR (relict, restored, and reconstructed), ISL (Inavale soil series), FSR (forb species richness), SSR (shrub species richness), and shrub cover (SC) all represented a mean decrease in model accuracy of $10 \%$ or more when removed from the model. LD (\% litter) and PANV (\% P. virgatum) represent a mean decrease in accuracy of just under $10 \%$. WP and $\mathrm{C} 2 \mathrm{M}$ represented the smallest decreases in the homogeneity of data subgroups when removed (Gini Index $<0.1)$.

\section{Partial dependence plots}

The relationship of various independent variables to Regal presence (REFR) was visualized utilizing partial dependence plots (Fig. 3; See Table 4 for variable descriptions). 
The binomial nature of the plotted VIOS and ISL variables appears linear with this analysis (both clearly positively related to REFR). As the number of data points increases from binary to count data to continuous data the complexity of the relationship is more clearly revealed. Count data (SSR) and scalar data (RRR) become rather blocky in appearance and continuous data provides a more multifaceted picture (ANDG, FC, and ISO). ANDG demonstrates a strong increase in the probability of Regals when percent cover reaches 50-55\%. ISO (Isolation) demonstrates a strong decrease in the probability of Regals when the measure reaches 500 (distance/permeability). This score can be interpreted as $500 \mathrm{~m}$ with a permeability of 1 (prairie) or $300 \mathrm{~m}$ at 0.60 permeability (river). FC demonstrates that as forb cover reaches $37-39 \%$ the probability of REFR starts to increase markedly. An almost linear increase in REFR is detectable as percent litter (LD) increases from 72 to $100 \%$. Finally, the highest probability of REFR exists at around 5\% P. virgatum cover (PANV) and decreases markedly as PANV increases from 8 to $18 \%$ cover.

\section{Discussion}

Our findings integrate habitat and land management variables to critically assess the contexts in which Regals persist in the prairies along the Big Bend of the Platte River. To best discuss our findings we developed a pathway model describing the ecological and management contexts of Regal habitat (Fig. 4). Our discussion follows the concepts laid out in the path model: habitat, land use history, size/isolation, management regime, and host plant.

\section{Habitat}

Tallgrass prairie with well-drained soils, located in the relatively drier portions of Platte River prairies, appears to provide the best habitat for Regals. First, Inavale series soils (ISL) were positively associated with Regal presence via all statistical measures (Tables 5, 8; Fig. 2). The welldrained nature of Inavale series soils means that moisture is not retained for long periods of time within the soil, and thus is not accessible to plants for an extended period of time when compared to heavier soils made of finer particles (clays, silts) that can also predominate in river valleys and wetlands. Inavale series soils are often present on the highest ridges in our riverine landscape and therefore are often less exposed to subsurface (subirrigated) moisture. Inavale series soils also tend to be some of the most sloped in the central Platte River prairies, increasing the rate of drainage from moisture events (USDA-NRCS 2011; USDA-NRCS
2015). Therefore, Inavale series soils are associated with relatively more xeric (drier) plant communities as compared with other common central Platte River Valley soil types such as Platte-Bolent Complex (See Tables 3, 5, 8; Fig. 3). Therefore, Inavale sandy loams, which make up $75 \%$ of the Inavale series soils in our sample, are described as "very rarely flooded" (USDA-NRCS 2015). The apparent necessity for specific soil moisture in Regal habitat has been detected in previous studies (See Mason 2001), but it is yet unclear whether this is related to the structure of the habitat, or some aspect of the Regal's biology.

Unsurprisingly, the plant community associated with the presence of Regals reflected well-drained soils as well. Monitoring plots with Regals were more dominated by upland (UPL, FACU) as opposed to mesic (FAC, FACW, OBL) graminoid species (Table 5). This tendency however, was not detected regarding forb species. This is possibly because graminoids made up a much larger percent $(73.36 \%)$ of the cover in the study area and were therefore more descriptive of the landscape hydrologically than forbs $(23.75 \%)$ or shrubs $(2.89 \%)$. P. oligosanthes is an example of a graminoid species occasionally dominant at plots with Regals (50\%) that is not dominant at plots without Regals $(0.0 \%)$. Many of the dominant graminoids on plots without Regals indicated either mesic (Eleocharis spp., S. pectinata, Carex spp., P. virgatum) or more poorly drained, heavier soils (Schedonorus spp.) (Nawrocki 2011; Reed 1998). These species were not found to be dominant on plots with Regals (Table 7). This suggests that plots with heavier wetland or mesic soils generally did not provide essential habitat for Regals. Despite forbs not demonstrating the same trend as graminoids regarding dominant wetland indicator status, particular forb species may be indicative of the correct habitat requirements for Regals (Table 7; Appendix 1 in Supplemental Electronic Material). $C$. involucrata is also present as a dominant forb at multiple plots with Regals and like $P$. oligosanthes is an indicator of well-drained soils (LBJ 2016; Montana Natural Heritage Program 2016). There was a greater diversity of dominant plant species representative of the variety of habitats included in the "without Regals" condition as compared to the "with Regals" condition (Table 7). This is unsurprising as there are a great variety of habitat factors that could preclude use by Regals and a very specific set of conditions that promote use by Regals (Fig. 4). Several of the forbs dominant on plots without Regals are indicators of habitat types that do not appear to suit Regals for a variety of reasons. For example, $P$. lanceolata $(\mathrm{OBL})$ is indicative of wet meadows at the Crane Trust; whereas Cornus drummondii (FAC) is a shrub indicative of early woody encroachment. It is possible that Regals are dependent upon upland plant communities (specifically FACU), the soil moisture they indicate, or both habitat features. 
In the absence of thatch it has been found that Regal larvae die, possibly due to drying out, as the larvae are nocturnal and may be intolerant to sun exposure (Ferster and Vulinec 2010; Wagner et al. 1997). It is also possible that thatch provides cover from diurnal predators (e.g. songbirds) and nocturnal foraging is a predator avoidance strategy (Berger and Gotthard 2008). Other research indicates that bracken thatch may create comparatively warm microsites that speed the development of High Brown Fritillary (Argynnis adippe) larvae (Warren 1995). As a thatch producer, A. gerardii, a dominant native Facultative Upland (FACU) grass (graminoid), seems to be an important constituent of Regal habitat given our data. The thatch and litter that $A$. gerardii produces (senesced and decomposing plant materials) has been positively associated with Regal habitat in the literature (Mason 2001; Helzer 2012; Ferster and Vulinec 2010; Davis et al. 2007; Vogel et al. 2007). However, the level of thatch and litter present in the landscape is highly dependent on recent management (grazing, fire, etc.), and thus we treat the subject of litter (including thatch) under the heading of management regime. A. gerardii may also be broadly indicative of the appropriate soil moisture for Regal habitat. A. gerardii (ANDG) was positively associated with Regals via all measures (Tables 5, 6, 7, 8; Fig. 2). The percent cover of $A$. gerardii was approximately twice as high on plots with Regals as compared to plots without Regals (Table 6). Its presence as a dominant plant in some plots without Regals is consistent with its general dominance across drier portions of Platte River lowland tallgrass prairies (Kaul and Rolfsmeier 1993; Table 7). By contrast $P$. virgatum is a FAC plant that is more dominant in mesic grasslands than A. gerardii (Reed 1998). P. virgatum cover (PANV) was significantly negatively correlated with $A$. gerardii cover (ANDG), while being significantly positively correlated with our wetland plant (WP) measure (Table 8). Despite not demonstrating a significant negative association with Regal presence, comparative statistics and RFA provide some evidence that $P$. virgatum may be indicative of more mesic ecotopes that do not provide key habitat for Regals (Tables 6, 7; Fig. 2).

Though the literature specifies particular habitats of importance such as dry tallgrass prairie containing violets (Viola spp.), in the Nebraska Sandhills (a drier mixedgrass system), Regals are restricted to the more mesic bottomlands (Ratcliffe and Hammond 2002; Swengel 1997). Regals are likely associated with a particular soil moisture regime across varied systems (Mason 2001). This would consist of the wetter low-lying areas of the Nebraska Sandhills that are analogous to drier portions of the tallgrass prairie along the Platte River, including the sloped sandy ridges created by large historic floods. These ridges are dominated by the same important species for Regals ( $A$. gerardii and Viola spp.) as those found in the lower lying parts of the Sandhills prairie ecosystem, which is predominantly a mixed-grass system in areas of higher topography (Currier 1982; Ratcliffe and Hammond 2002).

\section{Land use history}

Our data also demonstrates that relict prairie seems to be a necessary condition for Regal habitat, based on the comparison of categorical variables between plots with and without Regals, correlation analyses, and RFA (Tables 5, 8; Fig. 2). The RRR (relict, restored, reconstructed) variable was one of the most important variables in terms of the mean decrease in model accuracy when removed, accounting for about $15 \%$ of the model's accuracy in predicting the absence or presence of Regals (Fig. 2). Also, the larval host plant (Viola spp.) is an indicator of untilled systems, associated, in this study as well as others, with relict prairie (Ferster and Vulinec 2010; Shepherd and Debinski 2005a; Thompson 2006). There were no active Regal populations at reconstructed or highly denuded and subsequently restored prairies. Interestingly there were no violets detected at these plots either. All active Regal plots were relict in status; however, $50 \%$ of the plots without Regals were also relict (Table 5). Absence in those habitats likely reflects incompatible management (early successional states, cases of shrub encroachment, etc.) or unsuitable habitat (wet meadow). Regals are just one of many declining butterfly species specifically associated with relict/ remnant prairies (Summerville et al. 2006), and their association with relict prairie is robustly corroborated in the literature (Powell et al. 2007; Shepherd and Debinski 2005a; Kelly and Debinski 1998).

\section{Patch size/isolation}

Isolation (ISO) was a very important predictor variable, encompassing both the linear distance from the nearest monitoring plot with Regals as well as the permeability of the space between these plots when considering the dominant vegetative structure and landscape features. This measure was one of the top three variables of importance regarding both accuracy and homogeneity (Gini index) of the data with regards to RFA and was also significant regarding correlation analyses and two-sample comparative tests (Tables 6, 8; Fig. 2). The literature demonstrates that Regals are poor dispersers resistant to crossing habitat edges with the ease of habitat generalists Lepidoptera and that populations require large intact pastures (Ries and Debinski 2001; Ferster and Vulinec 2010; Swengel and Swengel 1997). These findings are corroborated by our research; of the 56 documented Regals $82.1 \%$ (46/56) were found in two large adjacent relict pastures, making up 172 ha (424 acres) of the estimated 503 ha (1244 acre) 
study area. Poor dispersal ability as well as specialized and isolated habitat needs are documented predictors of extinction risk (Mace et al. 2008; McKinney 1997). As the tallgrass prairie in Nebraska is highly fragmented, every large intact population of Regals should be actively conserved and further fragmentation strongly avoided. Though intuitive, this is an important finding as little is known about Regal dispersal abilities or why they are so resistant to dispersal between fragments. For example, Auckland et al. (2004) found that Parnassius clodius, a butterfly with half the wingspan of Regals, had daily flights of 200-600 m and a dispersal of 1-2 km. Yet, in one study, Regals did not disperse across $4 \mathrm{~km}$ (determined by both mark recapture and genetic testing; Ferster and Vulinec 2010). Our data demonstrates the degree to which appropriate habitat is isolated from a Regal population is an important factor in predicting Regal presence or absence in that habitat. However, these results can be difficult to interpret because the measure of isolation includes distance with permeability as a divisor. The average monitoring plot with Regals had an isolation score of about 576 (range: 305-1395; Table 6). This generally equates to $576 \mathrm{~m}$ of prairie without obstruction, or for example, $563 \mathrm{~m}$ where $20 \mathrm{~m}$ of the connecting path is water, a slough for instance, presenting a barrier aside from contiguous prairie between a given monitoring plot and the closest plot with Regals [ISO $=576=543 \mathrm{~m} / 1$ (pra irie) $+20 \mathrm{~m} / 0.6$ (river)]. Common landscape-level barriers to uninterrupted prairie at the Crane Trust were generally linear in nature and included roads, rivers, large sloughs, and tree lines along bodies of water (Fig. 1). Based on our RFA model the probability of Regals declined markedly as the isolation score approached 500 and was almost nonexistent after the isolation score reached 1500 (Fig. 3). Five of the six plots with Regals had isolation scores of 740 or below, corresponding to linear distances of $740 \mathrm{~m}$ or less from the nearest monitoring plot with Regals. Our results suggest that distances as short as $800 \mathrm{~m}$ (0.5 miles) may limit colonization or that recolonization across such distances may take significant time, especially given prairie parcels fragmented by landscape features less permeable to dispersing Regals (i.e. tree lines). In 2012 drought conditions and relatively intensive cattle grazing may have combined to decrease Regal populations across suitable portions of the landscape and it is possible that some suitable areas have yet to be recolonized given the Regal's relatively limited dispersal abilities (pers. com. Daniel Glomski 2015; Ferster and Vulinec 2010).

\section{Management actions}

Habitat metrics such as percent litter, shrub cover, and species composition are dynamic and responsive to land management at various time scales, often demonstrating immediate effects with many actions having impacts lasting for decades (Gibson and Hulbert 1987; Abrams and Hulbert 1987; Briggs et al. 2002b; Mandle et al. 2011). Generally, in subsequent years following a fire in tallgrass prairie, percent ground cover as litter increases, graminoid and herbaceous plant production increases in the first few years before declining, and eventually woody species invasion and woody biomass increases (Gibson and Hulbert 1987; Bragg and Hulbert 1976). Research suggests Regals require litter and thatch (senesced plant materials) as well as prairie free of shrub encroachment, but further quantification of these metrics is needed (Moranz et al. 2014; Swengel et al. 2011). Our research demonstrates that litter abundance was positively related to the presence of Regals; the percent of ground cover as litter and duff (LD) was higher on sites with Regals and as LD increased in relation to the percent of exposed bare ground the probability of Regals increased (Tables 6, 8; Fig. 2). Our results corroborate findings in the literature that demonstrate the importance of litter to Regal habitat (Vogel et al. 2010; Davis et al. 2007; Helzer 2012). Our results also aid in the quantification of this balance. Monitoring plots with Regals averaged $92 \%$ ground cover as litter (range: $82-98 \%$ ) and our statistical modeling suggests that the probability of Regals is very low below $72 \%$ litter and increases linearly as litter reaches $100 \%$ ground cover (Table 6; Fig. 3). Utilizing an easily repeatable point-line intercept method, natural resource professionals interested in promoting Regals through land management should be able to assess the prairies they manage for Regal suitability based on the litter metric utilized in our study (Symstad et al. 2008; SODN-NPS 2012).

No monitoring plot with Regals had any detectable shrub encroachment via our data collection methods (Table 6). However, significant shrub encroachment was generally rare on plots without Regals as well, making the impact of shrub encroachment difficult to model statistically. Of the five monitoring plots with documented shrub encroachment, only two exceeded $2 \%$ shrub cover (Appendix 1 in Supplemental Electronic Material). RFA deals well with small data sets and nonlinear relationships (Cutler et al. 2007; Liaw and Wiener 2002; Breiman 2001) and demonstrated that Shrub Species Richness (SSR) and percent Shrub Cover (SC) each represented about a $10 \%$ mean decrease in model accuracy when removed from the analysis (Fig. 2). Based on the RFA model, the presence of a single shrub species decreases the likelihood of Regals, and the presence of two or more shrub species decreases the likelihood further (Fig. 3). Management in the South brown (SB) pasture over the last 10 years was "light" (Table 1) and can be considered "light" for a decade previous as well, with no controlled burning in more than 20 years. Two of the three monitoring plots in this pasture exhibited signs of significant shrub encroachment 
and subsequently no Regals, despite being relict and a short spatial distance from an active Regal population (Fig. 1; Appendix 1 in Supplemental Electronic Material). A lack of fire or other management focused on controlling woody species may have precluded Regals from utilizing these plots. Lett and Knapp (2005) demonstrated that even early stage shrub encroachment by Roughleaf Dogwood (Cornus drummondii) altered the structure and function of tallgrass prairie ecosystems reducing the thatch producing graminoid component Regals are dependent on. Moranz et al. (2014) argues that Regals are dependent on a system (tallgrass prairie) that is maintained by disturbances like grazing and fire, which are paradoxically detrimental to Regals as management practices on a localized scale (prairie butterfly paradox). Fire plays an important role in maintaining the tallgrass prairie, promoting forb diversity, and controlling shrub encroachment (Briggs et al. 2002a, 2005; Anderson 1990; Collins 1990; Bragg and Hulbert 1976; Gibson and Hulbert 1987; Twidwell et al. 2013; Abrams and Hulbert 1987; Currier 1982; Lett and Knapp 2005). However, it can also be detrimental to Regal populations, especially when used too frequently, applied over too large of an area, or in combination with intensive grazing (Moranz et al. 2014; Swengel et al. 2011). Therefore, it is important to develop and research nuanced management practices that both mimic historic fire and grazing disturbance regimes while also promoting Regal populations.

Before large-scale habitat fragmentation, disturbances like fire and grazing would very rarely have had the ability to extirpate Regals from a localized area. Today, however, without the availability of adjacent undisturbed relict tallgrass prairie to serve as a refugia next to a burnt and subsequently grazed pasture, these disturbances necessary for the maintenance of tallgrass prairie ecosystems can be very detrimental to Regal populations by decreasing litter, opening up bare ground, and killing overwintering larvae (Vogel et al. 2010; Moranz et al. 2014; Huebschman and Bragg 2000). Complete burns of isolated pastures or rotational burning on smaller pastures ( $<30$ ha) will lead to Regal extirpation (Swengel et al. 2011; Swengel 1996; Huebschman and Bragg 2000; Kelly and Debinski 1998; Moranz et al. 2014). Therefore, it is important that we re-evaluate common rotational burning practices focused on grazing production when working in areas with Regals. Common 3-4 year burning cycles have been shown to be too short to maximize Regal numbers (Swengel and Swengel 2007; Kelly and Debinski 1998; Moranz et al. 2014). Swengel and Swengel (2007) note that it may take up to 8 years after fire for an area to serve as a population refugia for Regals. Interestingly, Ruge pasture had been burned 9 years ago at the time of our study and it had the greatest number of Regals (39) in our study area, just under $70 \%$ of all the Regals counted
(Table 1). Generally, the management regime on pastures containing monitoring plots with Regals included "infrequent" fire (5-year cycle or longer) and "moderate" levels of grazing (Table 1; for more information see "Pasturelevel Land Management History and Regal Habitat" in Supplemental Electronic Material). Research indicates modified patch-burn grazing systems, encompassing reduced levels of grazing, focusing controlled burns and therefore grazing on a smaller portion of a pasture annually may serve as a useful management practice for Regals by effectively controlling shrub encroachment, promoting nectar resources, and maintaining unburned refugia for Regal larvae (Helzer 2012; Moranz et al. 2014). Swengel et al. (2011) advocates burning no more than $20 \%$ of a particular pasture in a given year. More research is needed, but balancing the need for periodic fires with the need to maintain sizeable unburned areas for up to 8 years to benefit Regals will likely also promote other species that succeed in more mature tallgrass prairies with significant thatch accumulation, such as Henslow's Sparrow (Ammodramus henslowii) and Shorteared Owls (Asio flammeus) (Swengel and Swengel 1999, 2007, 2014; Powell et al. 2007).

Habitat variables such as plant species richness, diversity, and exotic species dominance have been found to respond differentially to varying intensities of managed disturbance (grazing, fire) in prairie ecosystems (Vujnovic et al. 2002; Brudvig et al. 2007; Biondini et al. 1989). Vujnovic et al. (2002) finds that moderate levels of disturbance promoted plant diversity as compared to low levels of disturbance, but that high levels of disturbance promoted exotic invasive plant communities. These habitat variables, indirectly reflective of land management actions, have not been extensively investigated in relation to Regal populations (See Farhat et al. 2014). In our research, percent exotic species cover (PE) and the Simpson Diversity Index (SDI) were not significantly different on plots with and without Regals and were actually found to decrease the accuracy of the RFA model when predicting the presence of Regals (Tables 6, 8; Fig. 2). The lack of explanatory ability of SDI suggests the evenness of species was less important than the overall cover of particular categories of plants (i.e. forbs). Although PE did not differ between plots with and without Regals, no monitoring plots with Regals exceeded $40 \%$ PE, however, two plots without Regals exceeded 54\% PE; both of these plots were "restored" and had been planted with invasive exotic plant species for livestock forage previous to conservation ownership. By contrast, "reconstructed" plots had some of the lowest PE measurements in our data $(n=2,10.0$ and $2.0 \%)$, which could have biased the PE measurements for plots without Regals downward, as neither reconstructed plot contained either violets or Regals. If exotic plant invasions precluded 
Regal habitat use the rarity of such cases in our data, along with the large range of PE cover measurements across all monitoring plots $(2.0-65.3 \%)$, makes this relationship undetectable statistically.

Other indirect measures of management intensity such as forb cover (FC), forb species richness (FSR), and total species richness (TSR) were comparatively higher on plots with Regals, and positively associated with the presence of Regals to varying degrees (Tables 6, 8). However, FC was ranked as the second most important variable in predicting Regal presence regarding both RFA metrics, well above FSR and TSR (Fig. 2). Additionally, FC showed a stronger relationship than either species richness measure (TSR or FSR) with Regal presence (Table 8); suggesting that the amount of appropriate floral resources may be more important than the diversity of such resources (Table 8). Not surprisingly, FC and FSR were positively correlated (Table 8), signifying that as the FSR increased so did FC and visa versa. Our finding that SDI was not a significant predictor of Regal presence also indicates that the general abundance of nectar resources represented as forb cover (FC) may be more important in constituting Regal habitat than the number and proportional evenness of forb species (nectar resources) on the landscape. Our findings corroborate the existing literature on Regal habitat noting that robust floral nectar resources are associated with Regal presence and abundance (Helzer 2012; Davis et al. 2007; Selby 2007; Nagel et al. 1991; Huebschman 1998). Interestingly, floral resources as measured by FC or FSR, again highlight the "prairie butterfly paradox" as fires tend to increase the forb component (floral resources) of a prairie for several years following a fire (Moranz et al. 2014; Biondini et al. 1989; Gibson and Hulbert 1987).

\section{Host plant}

Viola sororia (Common Blue Violet) presence was strongly associated with Regal presence by all measures. It was much more common on plots with Regals, highly associated with Regal presence, and was ranked as the most important variable regarding both mean decrease in accuracy and mean decrease in the Gini Index when removed from the RFA model (Tables 5, 8; Fig. 2). V. sororia was rather sparsely distributed at monitoring plots averaging just 3\% cover on plots with Regals. This relatively sparse distribution detected via our methods indicates that it is rarely a dominant plant, but often a detectable component of relict prairie systems in the central Platte Valley, NE. Aside from being the larval food plant for Regals, and therefore necessary to reach metamorphosis, the presence of Viola spp. (VIOS) also appears to broadly specify the correct habitat for Regals, indicating the correct soil moisture regime as well as relict prairie status in our study area.
Literature indicates that $V$. sororia is found in relict pastures and grows optimally in well-drained soils (University of Illinois Extension 2016; Kelly and Debinski 1998). Our data supports this, as VIOS was positively correlated with relict status (RRR) and Inavale series soils (ISL) (Table 8). Consistent with the literature, both V. sororia and Regals were only present on relict monitoring plots and generally were not found in wet meadow systems (Hammond and McCorkle 1984; Swengel 1997). Additionally, V. sororia demonstrated an association with abundant floral resources; VIOS was positively associated with percent forb cover (FC) (Table 8). Interestingly, the response of tallgrass prairie violet species (Viola spp.) to controlled burning is not fully understood. Thompson (2006) finds that fire increases the number of flowers, plant vigor, and germination rates of $V$. pedata by removing litter and exposing bare ground. Conversely, Henderson (1990) found that drought in conjunction with fire could decrease the abundance of $V$. pedata. It may be that moderate disturbance regimes, associated with robust floral resources, also promote $V$. sororia in the correct contexts (sufficient moisture, etc.), further illustrating the complexities of the prairie butterfly paradox (Moranz et al. 2014; Vujnovic et al. 2002; Thompson 2006).

\section{Conclusion}

We find extensive support for our model (Fig. 4) that Regals require well-drained soils, tallgrass prairie habitat, large connected tracts of contiguous relict prairie containing violets (Viola spp.), and very moderate management regimes that remove shrubby cover and promote forb cover, while maintaining undisturbed refugia providing ample recovery time on burned and grazed patches for litter development. We also find evidence that Regals occupy specific habitat niches along the Big Bend of that Platte River, revealing a preference for ecotopes with drier more well drained soils (Inavale series soils) dominated by facultative upland plants, most prominently Big Bluestem (A. gerardii). These results corroborate the findings from existing literature, further describe the contexts where Regals persist in the lowland tallgrass prairie present along the Platte River, and also contribute broadly to an understanding of Regal habitat needs and the management contexts under which they are found. These findings integrate variables regarding habitat associations, such as plant and soil associations, as well as land management variables, allowing us to describe appropriate habitat incorporating the interplay between the more stable characteristics of ecotopes and the more dynamic nature of land management. However, this study focuses on a rather specific context and more work is needed to contextualize Regal habitat at a greater spatial scale across more varied 
ecosystems and within additional management regimes over longer periods of time to further determine appropriate habitat characteristics and management strategies in those systems. This is especially true regarding the scattered tracts of tallgrass prairie west of the Regals historic core range that now retain some of the most robust metapopulations (Selby 2007). Significantly, our results support the lack of dispersal for this species, and therefore highlight the urgent need for conservation planning before the remaining metapopulations become dangerously isolated (see Ries and Debinski 2001 for dispersal; Ferster and Vulinec 2010 for genetic isolation and metapopulations). We suggest that additional research into the relationship of Regal populations and experimental management techniques such as "patch-burn grazing" with close attention to grazing intensity (stocking rates), fire timing and frequency, and refugia characteristics is needed to further develop effective Regal habitat management techniques (Helzer 2012; Moranz et al. 2014; Swengel and Swengel 2007; Swengel et al. 2011). This important species has faced precipitous declines, extirpation from ten states and Canada, and now faces a federal listing under the endangered species act (Selby 2007). Effective conservation and management in the immediate future is needed to limit further declines of this tallgrass prairie endemic butterfly.

Acknowledgements We would like to thank Chuck Cooper President/CEO and Brice Krohn Vice President at the Crane Trust for supporting our biological monitoring work related to Regal Fritillaries, Dan Glomski of the Edgerton Explorit Center for his dedication to Regal Fritillaries and his expert advice, Ross McLean and Katie Leung for their support in biological monitoring efforts, Mike Fritz of Nebraska Game and Parks for urging us to attempt this project, and Kenny Dinan and Kirk Schroeder of the US FWS for their dedication to pollinator work on private lands in Nebraska. Finally, we want to give a big thanks to the Nebraska Environmental Trust for providing grant funding through the REACH (Research Experience to Achieve Conservation of Habitat) program for this project, and Dr. Mary Harner of the University of Nebraska-Kearney for her role in securing that funding. Without all of you the important work of studying and conserving the remaining tracts of tallgrass prairie in Nebraska and the Regal Fritillaries that call it home would not be possible.

Open Access This article is distributed under the terms of the Creative Commons Attribution 4.0 International License (http:// creativecommons.org/licenses/by/4.0/), which permits unrestricted use, distribution, and reproduction in any medium, provided you give appropriate credit to the original author(s) and the source, provide a link to the Creative Commons license, and indicate if changes were made.

\section{References}

Abrams MD, Hulbert LC (1987) Effect of topographic position and fire on species composition on tallgrass prairie in northern Kansas. Am Midl Nat 111:442-445
Anderson RC (1990) The historic role of fire in the North American Grassland. In: Collins SL, Wallace LL (eds) Fire in North American tallgrass prairies. University of Oklahoma Press, Norman, pp 8-18

Auckland JN, Debinski DM, Clark WR (2004) Survival, movement, and resource use of the butterfly Parnassius clodius. Ecol Entomol 29(2):139-149

Berger D, Gotthard K (2008) Time stress, predation risk and diurnalnocturnal foraging trade-offs in larval prey ?. Behav Ecol Sociobiol 62(10): 1655-1663

Biondini ME, Steuter AA, Grygiel CE (1989) Seasonal fire effects on the diversity patterns, spatial distribution and community structure of forbs in the Northern Mixed Prairie, USA. Vegetation $85(1-2): 21-31$

Bragg TB, Hulbert LC (1976) Woody plant invasion of unburned Kansas bluestem prairie. J Range Manag 29(1):19-24

Breiman L (2001) Random forests. Mach Learn 45(1):5-32

Briggs JM, Hoch GA, Johnson LC (2002a) Assessing the rate, mechanisms, and consequences of the conversion of tallgrass prairie to Juniperus virginiana forest. Ecosystems 5(6):578-586

Briggs JM, Knapp AK, Brock BL (2002b) Expansion of woody plants in tallgrass prairie: a fifteen-year study of fire and fire-grazing interactions. Am Midl Nat 47:287-294

Briggs JM, Knapp AK, Blair JM, Heisler JL, Hoch GA, Lett MS, McCarron J K (2005) An ecosystem in transition causes and consequences of the conversion of mesic grassland to shrubland. BioScience 55(3):243-254

Brudvig LA, Mabry CM, Miller JR, Walker TA (2007) Evaluation of central North American prairie management based on species diversity, life form, and individual species metrics. Conserv Biol 21(3):864-874

Bruhjell D, Moore T (2003) Monitoring Riparian Areas. Riparian Factsheet Series (number 7 of 7). British Columbia Ministry of Agriculture, Food, and Fisheries. http://www2.gov.bc.ca/ assets/gov/farming-natural-resources-and-industry/agricultureand-seafood/agricultural-land-and-environment/water/riparian/810210-20_monitoring_riparian_areas.pdf. Accessed 10 Nov 2015

Collins SL (1990) Introduction: fire as a natural disturbance in tallgrass prairie ecosystems. In: Collins SL, Wallace LL (eds) Fire in North American tallgrass prairies. University of Oklahoma Press, Norman, pp 3-7

Currier PJ (1982) The floodplain vegetation of the Platte River: phytosociology, forest development, and seedling establishment. Dissertations, Iowa State University

Cutler DR, Edwards TC, Beard KH, Cutler A, Hess KT, Gibson JC, Lawler JJ (2007) Random forests for classification in ecology. Ecology 88(11):2783-2792

Daubenmire RF (1959) A canopy-coverage method of vegetational analysis. Northwest Sci 33:43-64

Davis JD, Debinski DM, Danielson BJ (2007) Local and landscape effects on the butterfly community in fragmented Midwest USA prairie habitats. Landscape Ecol 22:1341-1354

Dover JW, Warren MS, Shreeve TG (2011) 2010 and beyond for Lepidoptera. J Insect Conserv 15:1-3

Farhat YA, Janousek WM, McCarty JP, Rider N, Wolfenbarger LL (2014) Comparison of butterfly communities and abundances between marginal grasslands and conservation lands in the eastern Great Plains. J Insect Conserv 18:245-256

Fay DS, Gerow K (2013) A biologist's guide to statistical thinking and analysis. WormBook. doi:10.1895/wormbook.1.159.1

Ferster B, Vulinec K (2010) Population size and conservation of the last eastern remnants of the regal fritillary, Speyeria idalia (Drury) [Lepidoptera, Nymphalidae]; implications for temperate grassland restoration. J Insect Conserv 14:31-42 
Gibson DJ, Hulbert LC (1987) Effects of fire, topography, and yearto-year climatic variation on species composition in tallgrass prairie. Vegetation 72:175-185

Glomski D (2015) Senior Educator, Edgerton Explorit Center, Aurora NE, 68818. Former Program Manager, Crane Trust Nature and Visitor Center, Alda NE 68883. Conducted unpublished Lepidoptera research at the Crane Trust from 2009 to 2012. Personal Communication 11/15/2015

Google (2015) Google Earth (Version 7) [Computer program]. Aerial imagery 1993-2013

Hammond PC, McCorkle DV (1984) The decline and extinction of Speyeria populations resulting from human environmental disturbances. J Res Lepid 22:217-224

Helzer C (2009) The ecology and management of prairies in the central United States, Bur Oak Book. University of Iowa Press, Iowa City

Helzer C (2012) Regal Fritillary butterflies in burned and grazed prairie. The Nature Conservancy, The Prairie Ecologist. http:// prairieecologist.com/2012/11/13/regal-fritillary-butterflies-inburned-and-grazed-prairie/. Accessed 12 Dec 2015

Helzer C, Jasnowski M (2011) Results from 2011 Regal Fritillary butterfly surveys in the nature conservancy's Platte River Prairies, Nebraska. The Nature Conservancy, The Prairie Ecologist. https://theprairieecologist.files.wordpress.com/2011/12/2 011regalbflysummary_platte1.pdf. Accessed 10 Jan 2016

Henderson RA (1990) Ten-year response of a Wisconsin prairie remnant to seasonal timing of fire. In: Smith DD, Jacobs CA (eds) Proceedings of the twelfth North American prairie conference: recapturing a vanishing heritage. University of Northern Iowa, Cedar Falls, pp 121-125

Herrick JE, Van Zee JW, Havstad KM, Burkett LM, Whitford WG (2009) Monitoring manual for grassland, Shrubland and Savanna ecosystems: volumes I and II. USDA-ARS Jornada Experimental Range, Las Cruces

Huebschman JJ (1998) The relationship between nectar sources and Regal Fritillary (Speyeria idalia Drury) butterfly populations. Thesis, University of Nebraska

Huebschman JJ, Bragg TB (2000) Response of Regal Fritillary (Speyeria idalia Drury) to spring burning in an eastern Nebraska tallgrass prairie, USA. Nat Area J 20(4):386-388

Kaul R, Rolfsmeier S (1993) Native vegetation of Nebraska. UNL Conserv Surv Div. http://nebraskamaps.unl.edu. Accessed 30 Jan 2016

Kelly L, Debinski DM (1998) Relationship of host plant density to size and abundance of the Regal Fritillary Speyeria idalia drury (Nymphalidae). J Lepid Soc 52:262-276

Kopper BJ, Charlton RE, Margolies DC (2000) Oviposition site selection by the regal fritillary, Speyeria idalia, as affected by proximity of violet host plants. J Insect Behav 13(5):651-665

Kothmann MM, Hinnant RT (1993) The Grazing Manager: an operational level Grazing management decision aid. Project range care: managing livestock stocking. Department of Rangeland Ecology and Management, Texas Agricultural Extension Service, Texas A\&M University, College Station. http://texnat. tamu.edu/files/2010/09/managing_livestock_stocking_rates_ on_rangeland.pdf. Accessed 10 Nov 2015

LBJ WFC, Lady Bird Johnson Wild Flower Center (2016) Native plant database. The University of Texas, Austin. https://www. wildflower.org/plants/. Accessed 10 Feb 2016

Lett MS, Knapp AK (2005) Woody plant encroachment and removal in mesic grassland: production and composition responses of herbaceous vegetation. Am Midl Nat 153(2):217-231

Liaw A, Wiener M (2002) Classification and regression by Random Forest. R News 2(3):18-22

Mace GM, Collar NJ, Gaston KJ, Hilton-Taylor C, Akaya HRA, Leader-Williams N, Milner-Gulland EJ, Stuart SN (2008)
Quantification of extinction risk: IUCN's system for classifying threatened species. Conserv Biol 22(6):1424-1442

Mandle L, Bufford JL, Schmidt IB, Daehler CC (2011) Woody exotic plant invasions and fire: reciprocal impacts and consequences for native ecosystems. Biol Invasions 13(8):1815-1827

Mason KR (2001) Comparison of prairie sites and classification of their habitat attributes in relation to abundance of the Regal Fritillary butterfly (Speyeria idalia). Minnesota Department of Natural Resources. http://files.dnr.state.mn.us/eco/nongame/ projects/consgrant_reports/2001/2001_mason.pdf. Accessed 20 Nov 2015

McKinney ML (1997) Extinction vulnerability and selectivity: combining ecological and paleontological views. Annu Rev Ecol Syst 28:495-516

Montana Natural Heritage Program (2016) Scribner's Panic Grass-Dichanthelium oligosanthes var. scribnerianum. Montana Field Guide. http://fieldguide.mt.gov/speciesDetail. aspx? elcode $=$ pmpoa240q2. Accessed 15 Apr 2016

Moranz RA, Fuhlendorf SD, Engle DM (2014) Making sense of a prairie butterfly paradox: the effects of grazing, time since fire, and sampling period on regal fritillary abundance. Biol Conserv 173:32-41

Muldavin E, Collins S (1999) Core research site web quadrat data for the net primary production study at the Sevilleta National Wildlife Refuge, New Mexico (1999-2015): methods. Sevilleta LTER (Long Term Ecological Research) Station, the University of New Mexico Albuquerque. http://sev.lternet.edu/ data/sev-129. Accessed 15 April 2015

Nagel HG, Nightengale T, Dankert N (1991) Regal fritillary butterfly population estimation and natural History on Rowe Sanctuary, Nebraska. Prairie Nat 23:145-152

Naveh Z (1994) From biodiversity to ecodiversity: a landscapeecology approach to conservation and restoration. Restor Ecol 2(3):180-189

Nawrocki T (2011) Tall Fescue: Schedonorus arundinaceus (Schreb.) Dumort. Alaska Natural Heritage Program, University of Alaska Anchorage. http://aknhp.uaa.alaska.edu/wp-content/uploads/2013/01/Schedonorus_phoenix_BIO_SCPH.pdf. Accessed 16 Feb 2016

Noss RF, LaRoe ET, Scott JM (1995) Endangered ecosystems of the United States: a preliminary assessment of loss and degradation, vol 28. U.S. Department of the Interior, National Biological Service, Washington

Pollard E (1977) A method for assessing changes in the abundance of butterflies. Biol Conserv 12(2):115-134

Powell AF, Busby WH, Kindscher K (2007) Status of the regal fritillary (Speyeria idalia) and effects of fire management on its abundance in northeastern Kansas, USA. J Insect Conserv 11(3):299-308

R Core Team (2015). R: a language and environment for statistical computing. R Foundation for Statistical Computing, Vienna. http://www.R-project.org/. Accessed 10 Dec 2015

Ratcliffe BC, Hammond PC (2002) Insects and the native vegetation of Nebraska. Trans Nebraska Acad Sci 28:29-47

Reed PB Jr (1988) National list of Plant Species that Occur in Wetlands: National Summary. US Fish Wildl Serv Biol Rep 88(24):244

Ries L, Debinski DM (2001) Butterfly responses to habitat edges in the highly fragmented prairies of Central Iowa. J Anim Ecol $70: 840-852$

Selby G (2007) Regal Fritillary (Speyeria idalia Drury): a technical conservation assessment. USDA Forest Service, Rocky Mountain Region, Species Conservation Project 
Shepherd S, Debinski DM (2005a) Evaluation of isolated and integrated prairie reconstructions as habitat for prairie butterflies. Biol Conserv 126:51-61

Shepherd S, Debinski DM (2005b) Reintroduction of Regal Fritillary (Speyeria idalia). Ecol Restor 23:244-250

SODN-NPS, Sonoran Desert Network Inventory \& Monitoring Program, National Park Service (2012) Uplands monitoring in the Sonoran Desert Network and Chihuahuan Desert Network: protocol summary. National Park Service, Department of the Interior. http://science.nature.nps.gov/im/units/sodn/. Accessed 15 April 2015

Spellerberg IF, Fedor PJ (2003) A Tribute to Claude Shannon (1916-2001) and a Plea for more rigorous use of species richness, species diversity and the Shannon-Wierner' Index. Glob Ecol Biogeogr 12:117-179

Summerville KS, Conoan CJ, Steichen RM (2006) Species traits as predictors of lepidopteran composition in restored and remnant tallgrass prairies. Ecol Appl 16(3):891-900

Swengel AB (1996) Effects of fire and hay management on abundance of prairie butterflies. Biol Conserv 76(1):73-85

Swengel AB (1997) Habitat Associations of Sympatric Violet-feeding Fritillaries (Euptoieta, Speyeria. Boloria) (Lepidoptera: Nymphalidae) in Tallgrass Prairie. Great Lakes Entomol 30(1):1-18

Swengel SR (2015) Comments to USFWS on petition to list Regal Fritillary federally. Report submitted to Region 6 of the US Fish and Wildlife Service. http://www.regulations. gov/\#!documentDetail;D=FWS-R6-ES-2015-0078-0015. Accessed 25 Jan 2016

Swengel AB, Swengel SR (1997) Co-occurrence of prairie and barrens butterflies: applications to ecosystem conservation. J Insect Conserv 1:131-144

Swengel SR, Swengel AB (1999) Correlations in abundance of grassland songbirds and prairie butterflies. Biol Conserv 90(1):1-11

Swengel AB, Swengel SR (2007) Benefit of permanent non-fire refugia for Lepidoptera conservation in fire-managed sites. J Insect Conserv 11(3):263-279

Swengel AB, Swengel SR (2009) Spatiotemporal variation of violetfeeding large fritillaries (Euptoieta, Speyeria) (Lepidoptera: Nymphalidae) in Central and Northern Wisconsin. Great Lakes Entomol 42(3-4):121

Swengel SR, Swengel AB (2014) Short-eared Owl abundance and conservation recommendations in relation to site and vegetative characteristics, with note on Northern Harriers. Passeng Pigeon 76:51-68

Swengel SR, Schlicht D, Olsen F, Swengel AB (2011) Declines of prairie butterflies in the midwestern USA. J Insect Conserv 15:327-339

Symstad AJ, Wienk CL, Thorstenson AD (2008) Precision, repeatability, and efficiency of two canopy-cover estimate methods in northern Great Plains vegetation. Rangeland Ecol Manage 61:419-429

Thompson MJ (2006) Bird's-foot violet (Viola pedata) optimal microhabitat characteristics in Ontario tallgrass prairie remnants. Thesis, University of Quebec at Montreal

Twidwell D, Fuhlendorf SD, Taylor CA, Rogers WE (2013) Refining thresholds in coupled fire-vegetation models to improve management of encroaching woody plants in grasslands. J Appl Eco 50(3):603-613

University of Illinois Extension (2016) Wildflowers: Viola sororia. University of Illinois at Urbana-Champaign. http://extension. illinois.edu/wildflowers/directory_detail.cfm?PlantID=958. Accessed 25 Mar 2016

US Bureau of Reclamation-US Department of Interior (1938) Land classification maps: imagery from July 4th 1938 and November 19th 1938 aerial surveys. Retrieved from US FWS Private Lands Biologist Kirk Schroeder, Grand Island, NE

USDA-NCRS, United States Department of Agriculture-Natural Resources Conservation Service, Soil Survey Division (2011) Official Series Description: INAVALE Series. National Cooperative Soil Survey (NCSS). https://soilseries.sc.egov.usda.gov/osdname.asp. Accessed 13 Jan 2016

USDA-NRCS, United States Department of Agriculture- Natural Resources Conservation Service (2016) Growth habits codes and definitions. USDA Plants Database. http://plants.usda.gov/ growth_habits_def.html. Accessed 15 Jan 2016

USDA-NRCS, United States Department of Agriculture-Natural Resources Conservation Service, Soil Survey Division (2015) Maps for Hall County. Web Soil Survey. http://websoilsurvey. nrcs.usda.gov/. Accessed 15 Apr 2015

Vogel JA, Debinski DM, Koford RR, Miller JR (2007) Butterfly responses to prairie restoration through fire and grazing. Biol Conserv 140:78-90

Vogel JA, Koford RR, Debinski DM (2010) Direct and indirect responses of tallgrass prairie butterflies to prescribed burning. J Insect Conserv 14:663-677

Vujnovic K, Wein RW, Dale MR (2002) Predicting plant species diversity in response to disturbance magnitude in grassland remnants of central Alberta. Can J Bot 80(5):504-511

Wagner DL, Wallace MS, Boettner GH, Elkinton JS (1997) Status update and life history studies on the regal fritillary (Lepidoptera: Nymphalidae). In: Vickery PD, Dunwiddie P (eds) Grasslands of northeastern North America: ecology and conservation of native and agricultural landscapes. Massachusetts Audubon Society, Lincoln, pp 261-275

Warren MS (1995) Managing local microclimates for the high brown fritillary, Argynnis adippe. In: Pullin AS (ed) Ecology and conservation of butterflies. Springer, Dordrecht, pp 198-210 